\title{
Geohydrology and Potential for Upward Movement of Saline Water in the Cocoa Well Field, East Orange County, Florida
}

By G.G. Phelps and Donna M. Schiffer

U.S. GEOLOGICAL SURVEY

Open-File Report 95-736

Prepared in cooperation with

St. Johns River Water Management District

South Florida Water Management District

City of Cocoa, Florida

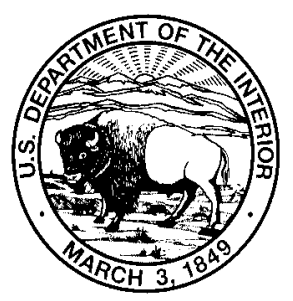




\title{
U.S. DEPARTMENT OF THE INTERIOR BRUCE BABBITT, Secretary
}

\author{
U.S. GEOLOGICAL SURVEY \\ Gordon P. Eaton, Director
}

For additional information write to:

District Chief

U.S. Geological Survey, WRD

227 N. Bronough Street, Suite 3015

Tallahassee, FL 32301
Copies of this report can be purchased from:

U.S. Geological Survey

Branch of Information Services

Federal Center

Box 25286

Denver, CO 80225-0286 


\section{CONTENTS}

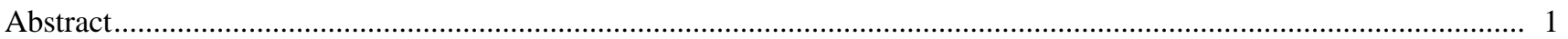

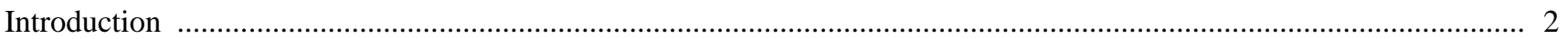

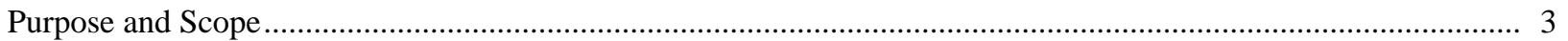

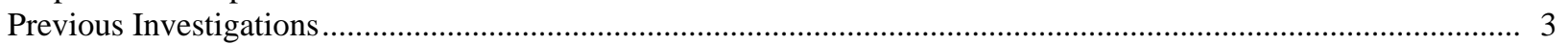

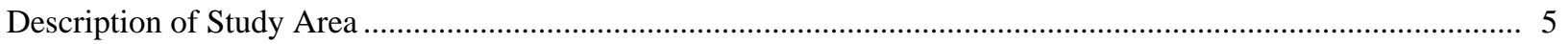

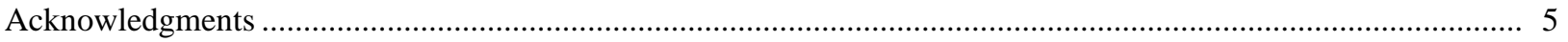

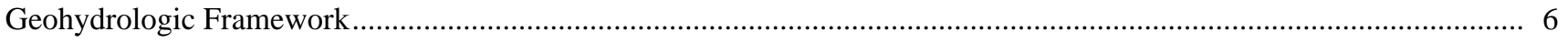

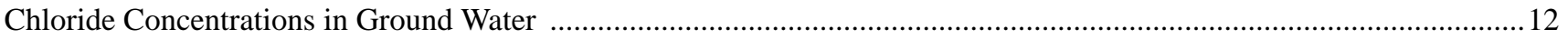

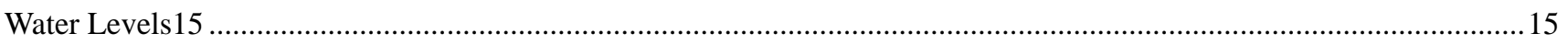

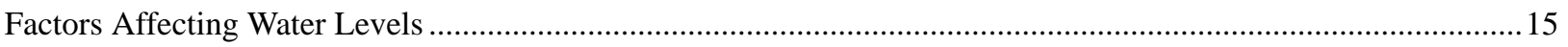

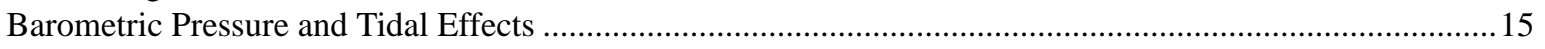

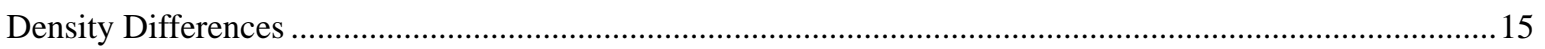

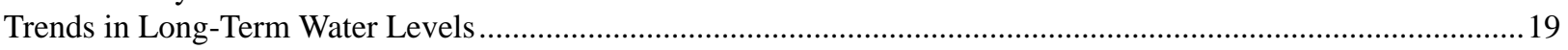

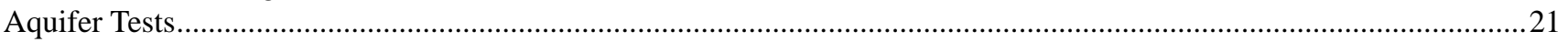

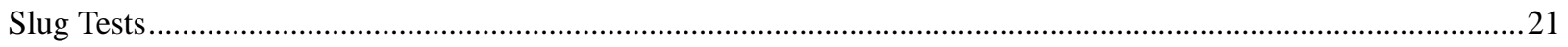

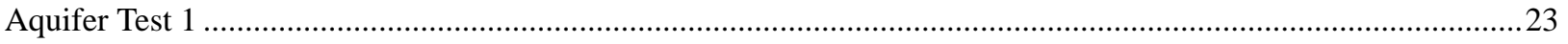

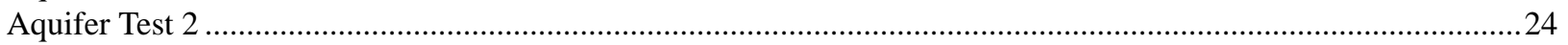

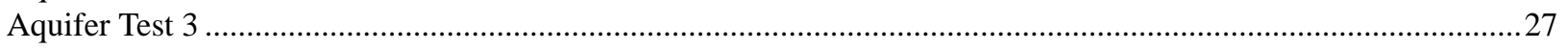

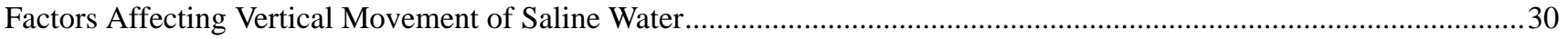

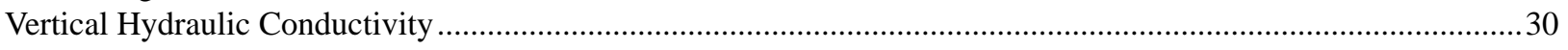

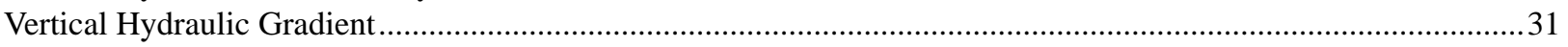

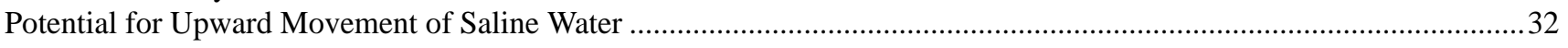

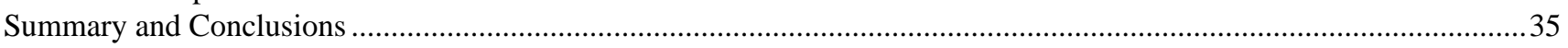

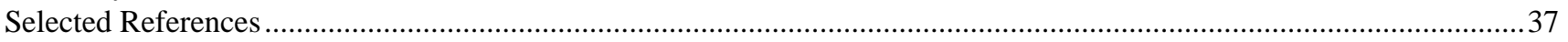

\section{FIGURES}

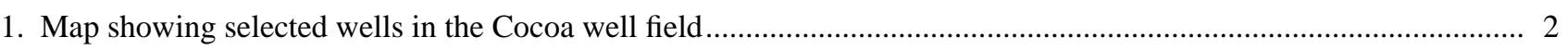

2. Graph showing chloride concentration in water from zone 1 of Cocoa C, 1966-94 .............................................. 5

3. Graph showing average monthly rainfall at Orlando, Fla., based on 30 years of record (1961-90) ........................... 6

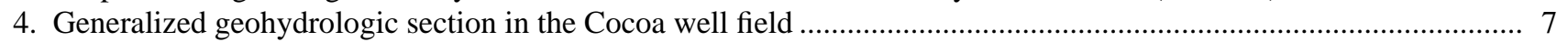

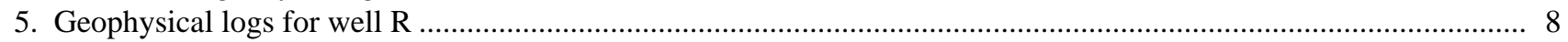

6. Geohydrologic section showing well-completion information for wells $\mathrm{C}$ and $\mathrm{R}$..................................................10

7. Map showing the potentiometric surface of the Upper Floridan aquifer in the vicinity of the

Cocoa well field, September 1993 ..............................................................................................................................

8. Map showing chloride concentration in water from the Upper Floridan aquifer, Orange County, Fla., and vicinity ...

9-14. Graphs showing:

9. Chloride concentrations in water from selected wells in the Cocoa well field, 1960-94 ......................................13

10. Chloride concentrations in water from zones of well C, 1966-94 ..................................................................... 14

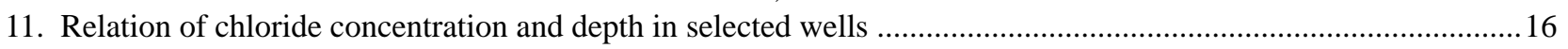

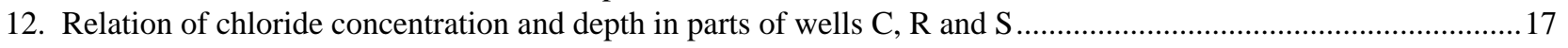

13. Water levels in well 1 at Bithlo, Fla., and Cocoa R, November 12-19, 1993 .....................................................18

14. Water levels in well $\mathrm{R}$ and barometric pressure, January 20-February 15, 1994 ................................................19

15. Diagram showing definitions of point-water, freshwater, and environmental-water heads in ground water

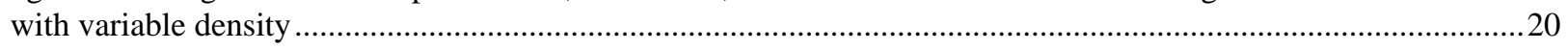

16. Graphs showing point-water heads in zones 1 and 3 of well C, equivalent freshwater head in zone 1 , and monthly rainfall at Orlando, Fla., 1966-94 ...... 
17. Graphs showing water levels in zones 3, 4, and 5 of well C, 1966-94, and in well Bithlo 1, 1974-94 ...................... 22

18. Graphs showing water-level response of zones 1,3 , and 4 in well $\mathrm{C}$ to slug tests .................................................24

19. Geohydrologic section showing well-completion data near well $\mathrm{C}$.....................................................................25

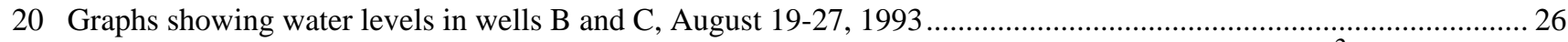

21. Graph showing relation of residual drawdown $(s)$ and ratios of time divided by distance squared $\left(t / r^{2}\right)$

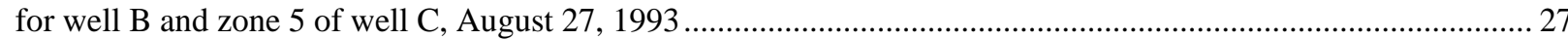

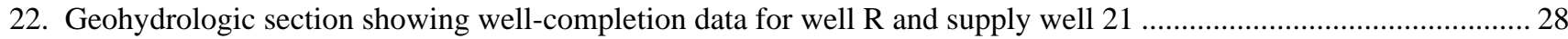

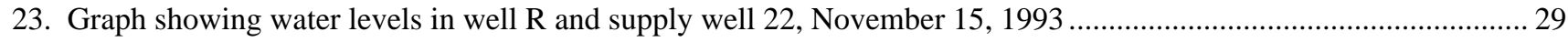

24. Graph showing water levels in zones 1 and 5 of well C, February 9, 1994...................................................3 30

25. Geohydrologic section identifying variables for calculating hydrostatic head in ground water with variable density

26. Graph showing difference between head in zone 3 of well $\mathrm{C}$ and calculated hydrostatic head at the

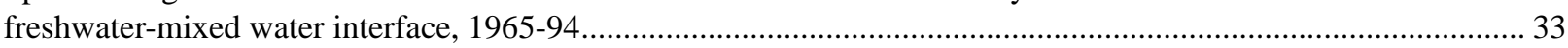

27. Graphs showing water levels in the Lake Ivanhoe well, Orlando, Fla., 1989-94 ...................................................... 34

28. Graph showing total monthly pumpage from wells 14 and 15 and chloride concentration in water from zones of well C, 1967-94.

\section{TABLES}

1. Selected wells in the Cocoa well field .....

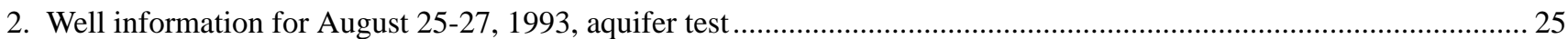

3. Pumping rates for February 9, 1994, aquifer test

CONVERSION FACTORS, VERTICAL DATUM, ABBREVIATIONS, AND WELL-NUMBERING SYSTEM

\begin{tabular}{rcl}
\hline Multiply & By & To obtain \\
& Length & \\
foot (ft) & 0.3048 & meter \\
inch (in.) & 25.4 & millimeter \\
mile (mi) & 1.609 & kilometer \\
& Volume & \\
gallon (gal) & 0.003785 & cubic meter \\
& Flow & \\
gallon per minute (gal/min) & 0.06309 & liter per second \\
million gallons per day (Mgal/d) & 0.04381 & cubic meter per second \\
& Hydraulic conductivity \\
foot per day (ft/d) & 0.3048 & meter per day \\
& Transmissivity & \\
foot squared per day (ft2/d) & 0.0929 & meter squared per day \\
& Acceleration & \\
foot per second, squared (ft/s2) & 0.3048 & meter per second, squared \\
\end{tabular}

Sea level: In this report "sea level" refers to the National Geodetic Vertical Datum of 1929—a geodetic datum derived from a general adjustment of the first-order level nets of the United States and Canada, formerly called Sea Level Datum of 1929.

Altitude, as used in this report, refers to distance above or below sea level.

Transmissivity: The standard unit for transmissivity is cubic foot per day per square foot times foot of aquifer thickness $\left[\left(\mathrm{ft}^{3} / \mathrm{d}\right) / \mathrm{ft}^{2}\right] \mathrm{ft}$. In this report, the mathematically reduced form, foot squared per day $\left(\mathrm{ft}^{2} / \mathrm{d}\right)$, is used for convenience.

Specific conductance is given in microsiemens per centimeter at 25 degrees Celsius $\left(\mu \mathrm{S} / \mathrm{cm}\right.$ at $\left.25{ }^{\circ} \mathrm{C}\right)$.

Concentrations of chemical constituents in water are given in milligrams per liter $(\mathrm{mg} / \mathrm{L})$. 


\section{ABBREVIATIONS}

NOAA National Oceanic and Atmospheric Administration

$\mathrm{mg} / \mathrm{L} \quad$ milligrams per liter

min minute

SFWMD South Florida Water Management District

SJRWMD St. Johns River Water Management District

USGS U.S. Geological Survey

WATSTORE U.S. Geological Survey's National Water Data Storage and Retrieval System

\section{Well-Numbering System}

The supply well numbers in this report were assigned by the city of Cocoa. Supply-well numbers were assigned in the general order in which the wells were drilled. Observation wells were assigned letters in the general order in which the wells were incorporated into the monitoring-well network. A second well-numbering system used in this report, a 15-digit number based on latitude and longitude, identifies wells in the U.S. Geological Survey's National Water Data Storage and Retrieval System (WATSTORE). The first 6 digits denote the degrees, minutes, and seconds of latitude; the next 7 digits denote degrees, minutes, and seconds of longitude; and the last 2 digits denote a sequential number of a well site within a 1-second grid. For example, well 282532081075601 (Cocoa B) is the first well inventoried at latitude $28^{\circ} 25^{\prime} 32^{\prime \prime} \mathrm{N}$, longitude $081^{\circ} 07^{\prime} 56^{\prime \prime} \mathrm{W}$. 
VI Contents 


\title{
Geohydrology And Potential For Upward Movement Of Saline Water In The Cocoa Well Field, East Orange County, Florida
}

\author{
By G. G. Phelps and Donna M. Schiffer
}

\section{ABSTRACT}

The Floridan aquifer system, an approximately 2,000-foot thick sequence of Eocene-age limestone and dolomite, is the main source of water supply in central Florida. Hydraulic conductivity is different in strata of different lithology and is the basis for separating the aquifer system into the Upper Floridan aquifer, a middle semi-confining unit, and the Lower Floridan aquifer. The coastal city of Cocoa withdraws about 26 million gallons of water per day from the Upper Floridan aquifer from a well field in east Orange County, about 25 miles inland. About 60 million gallons per day are withdrawn from the Upper Floridan aquifer and 56 million gallons per day from the Lower Floridan aquifer in the Orlando area, about 15 miles west of the Cocoa well field.

Wells drilled in the Cocoa well field from 1955-61 yielded water with chloride concentrations ranging from 25-55 milligrams per liter. Soon after the wells were put in service, chloride concentrations increased; therefore, new wells were drilled further inland. Chloride concentrations in water from many of the new wells also have increased. Possible sources of saline water are lateral movement of relict seawater in the Upper Floridan aquifer from the east, regional upconing of saline water from the Lower Floridan aquifer or underlying older rocks, or localized upward movement of saline water through fractures. Several test wells were drilled to provide information about chloride concentration changes with depth and to monitor changes with time, including a multi-zone well drilled in 1965 (well C) and two wells drilled in the 1990's (wells R and S). Chloride concentrations have increased in the zone pumped by the supply wells (the upper 500 feet of the aquifer) and in the 1,351-1,357-foot deep zone of well C, but not in the two intervening zones. This indicates that the source of saline water is located laterally, rather than vertically, from the pumped zone in the area of well C.

The potential for upward movement of saline water depends on the direction of the vertical hydraulic gradient and on the vertical hydraulic conductivity of the aquifer. A series of aquifer tests was run in 1993-94 and existing water-level and water-quality data were analyzed to evaluate the potential for upward movement of saline water in the well field. The transmissivity of the upper 500 feet of the aquifer is about 100,000 feet squared per day (the horizontal hydraulic conductivity is about 200 feet per day) and the storage coefficient is about $2 \times 10^{-4}$. Horizontal hydraulic conductivities determined from slug tests of the three deepest zones of well $\mathrm{C}$ ranged from 20-50 feet per day. Vertical hydraulic conductivities probably do not exceed 0.05 feet per day.

The vertical hydraulic gradient is determined by comparing water levels in the various zones, but because of density differences, unadjusted water levels in the deepest zone investigated cannot be directly compared to water levels in the overlying freshwater zones. The difference between environmental-water heads (adjusted for density differences) in the saline-water zone of 
well $\mathrm{C}$ and the overlying freshwater zone were calculated from measured water levels for the period 1966 to 1994. During most of this time period, the gradient was downward, indicating that saline water did not move upward.

Upconing of saline water probably is not taking place in the center and western part of the well field, based on the low vertical hydraulic conductivity values estimated for the middle semi-confining unit, the generally downward vertical hydraulic gradient, and the constant chloride concentrations in the intermediate zones of well $\mathrm{C}$. However, there is no information about the extent of the zone of low vertical hydraulic conductivity or about the direction of the vertical hydraulic gradient in the eastern part of the well field. Thus, increased chloride concentrations in supply wells in the eastern part of the well field could be caused either by lateral movement of saline water from the east, or by upward movement from the
Lower Floridan aquifer if the low conductivity zone is thin or breached by fractures, or by a combination of both lateral and vertical movement.

\section{INTRODUCTION}

The city of Cocoa in Brevard County, Florida, has withdrawn water from the Floridan aquifer system in East Orange County, Florida, since 1955 when the Cocoa well field (fig. 1) was constructed. The city of Cocoa supplies water for much of central Brevard County. The well field is located $25 \mathrm{mi}$ inland because of the saline water which underlies most of Brevard County and the extreme eastern part of Orange County. The term saline water, as used in this report, is defined as water with a chloride concentration greater than $250 \mathrm{mg} / \mathrm{L}$.

The original 13 wells in the Cocoa well field (numbers 1-11 and 12A and 12B, fig. 1) were drilled from 1956 to 1961 and collectively have a capacity to

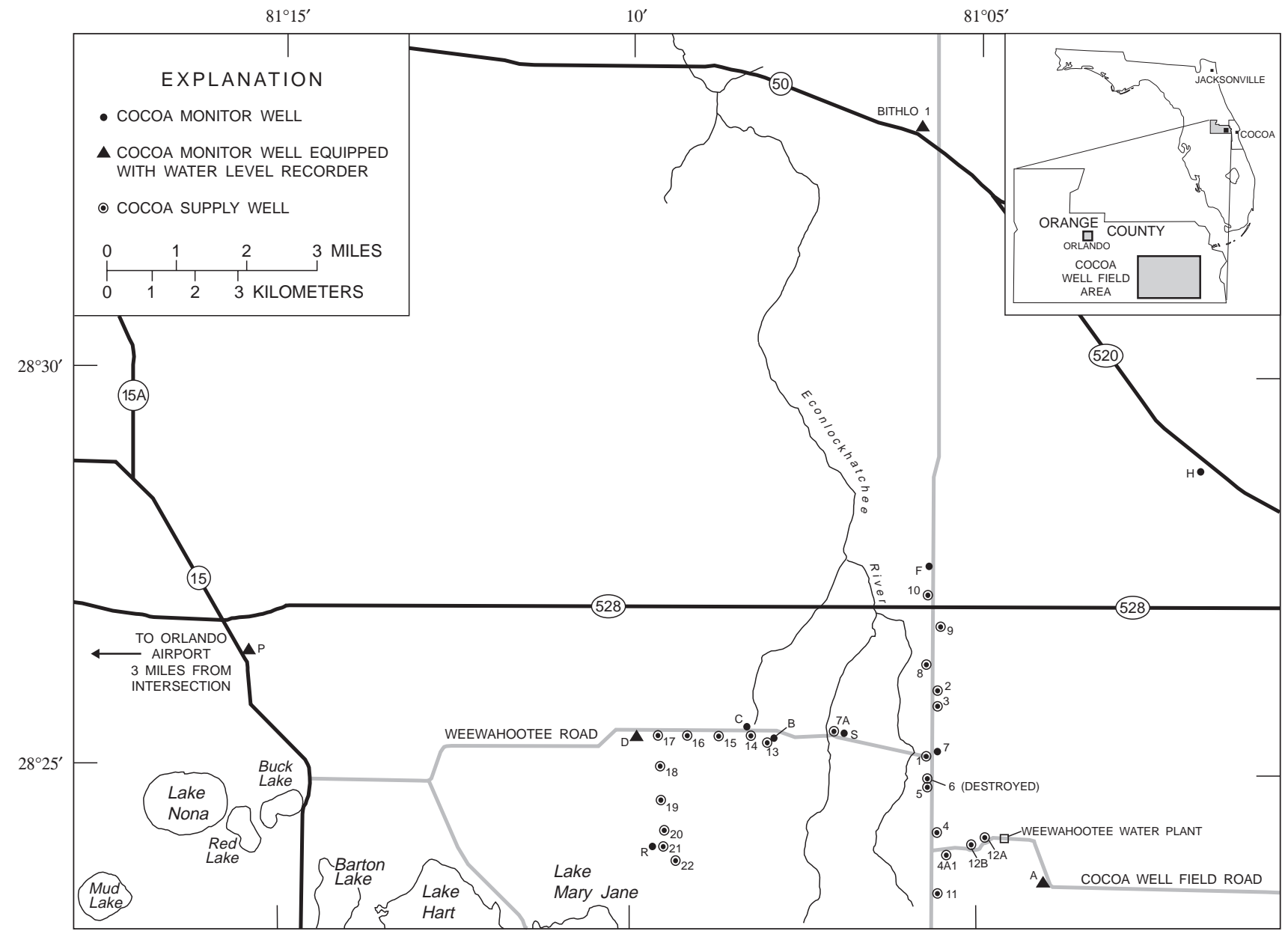

Figure 1. Location of selected wells in the Cocoa well field. 
produce $17.5 \mathrm{Mgal} / \mathrm{d}$. Chloride concentrations in many of these wells began to increase soon after being put into service and the regular use of some of the wells was discontinued. Some of the original 13 wells were placed on standby and some were plugged back to shallower depths. These 13 wells are referred to collectively as the "old well field." Six additional wells (numbers 7A and 13-17, fig. 1), with a combined capacity of $12 \mathrm{Mgal} / \mathrm{d}$, were drilled beginning in 1962 along an east-west line to avoid further increases in chloride concentrations in water from wells in the old well field. Well 4A1 was drilled in the 1970's. Wells 18-22 were drilled between 1984 and 1992. Well 7A and all wells to the west are referred to collectively as the "new well field." Well locations are shown in figure 1 and well depths are listed in table 1.

A multi-zone well (Cocoa $\mathrm{C}$ ) was constructed in 1965 to monitor the salinity of water in several zones of the Floridan aquifer system. Cocoa $\mathrm{C}$ is located about $180 \mathrm{ft}$ from the city of Cocoa's supply well 14 . Chloride concentrations in water from the deepest zones are monitored to detect possible upward movement of saline water from lower zones.

The deepest zone of well C (zone 1) is completed in the upper part of the Lower Floridan aquifer, between 1,351-1,357 ft below land surface. Chloride concentrations in zone 1 have increased from $625 \mathrm{mg} / \mathrm{L}$ in 1966 to about 3,000 mg/L in 1994 (fig. 2). A second salinity monitoring well (Cocoa R), drilled in June 1991 , is open to a zone from 1,098-1,205 ft below land surface. Chloride concentrations in water samples collected during drilling of this well increased from $70 \mathrm{mg} / \mathrm{L}$ at $1,100 \mathrm{ft}$ below land surface to about $250 \mathrm{mg} / \mathrm{L}$ at $1,200 \mathrm{ft}$ below land surface.

The uppermost zone of well $\mathrm{C}$ (zone 5) is open from 248-1,004 ft below land surface and is used to monitor the zone of the Upper Floridan aquifer used for water supply. Chloride concentrations in zone 5 and in some supply wells in the new well field also have increased. In 1993, increasing chloride concentrations in the water in well 15 (from about 50 to about $100 \mathrm{mg} / \mathrm{L}$ ) prompted the reduction of the pumping rate and the amount of pumping time for that well. A possible source of the increased chloride in well 15 might be upconing of water from deeper zones of the aquifer system near well 15.

No quantitative data are available to estimate the rate at which saline water can move upward from the Lower Floridan aquifer to the zone that is used for water supply. Vertical hydraulic conductivity values generated from calibrated ground-water flow models are regional in scope. More site-specific information is needed to estimate the rate of possible upward movement of saline water, which is a function of the hydraulic properties of the aquifers and confining layers between the aquifers and of the magnitude and direction of the vertical hydraulic gradient. The U.S. Geological Survey (USGS), in cooperation with the St. Johns River Water Management District (SJRWMD), the South Florida Water Management District (SFWMD), and the city of Cocoa, began a two-year study in the Cocoa well field in 1993 to determine aquifer properties of the confining zones between the Lower Floridan aquifer (zone 1) and the Upper Floridan aquifer zone used for water supply (zone 5) using a series of aquifer tests.

\section{Purpose and Scope}

This report presents the results of three slug tests, three aquifer tests, and the analysis of data from these tests to evaluate hydraulic properties of the zones of the Floridan aquifer system in the Cocoa well field. The geohydrology of the Cocoa well-field area is described and long-term hydrographs and waterquality data are presented. Factors affecting water levels, including barometric pressure and density differences resulting from salinity content are discussed. Analytical techniques used in this investigation and described in this report include a method for aquifer test analysis described by Neuman and Witherspoon (1972) and a method for slug-test analysis described by Van der Kamp (1976). The potential for upward movement of saline water in the Cocoa well field is evaluated. Possible reasons for the increasing chloride concentrations in zone 1 of the Cocoa $\mathrm{C}$ monitoring well and other wells in the well field are discussed.

\section{Previous Investigations}

Ground-water resources in the Cocoa well field have been described in several reports. Tibbals and Frazee (1976) described the general geohydrology of the area, including an analysis of the potential for saline-water upconing, based on observed water levels and water quality. A report on the drilling in 1991 of three new production wells and one monitoring well for the city of Cocoa was prepared by the consulting firm $\mathrm{CH} 2 \mathrm{M}$ Hill and includes a description of geology and water quality based on the results of sampling the 
Table 1. Selected wells in the Cocoa well field

[All wells are open hole. UF, Upper Floridan aquifer; LF, Lower Floridan aquifer; MS, Middle semi-confining unit]

\begin{tabular}{|c|c|c|c|c|c|}
\hline Site identification number & Well name & $\begin{array}{c}\text { Depth } \\
\text { (ft) }\end{array}$ & $\begin{array}{c}\text { Depth cased } \\
\text { (ft) }\end{array}$ & Use & $\begin{array}{c}\text { Geohydrologic } \\
\text { unit }\end{array}$ \\
\hline 283249081053201 & Bithlo 1 & 492 & 151 & Supply & UF \\
\hline 282510081054501 & Cocoa 1 & 374 & 316 & Supply & UF \\
\hline 282612081054201 & Cocoa 2 & 616 & 271 & Supply & UF \\
\hline 282548081054201 & Cocoa 3 & $a_{374}$ & 266 & Supply & UF \\
\hline 282416081054101 & Cocoa 4 & 524 & 251 & Supply & UF \\
\hline 282405081053002 & Cocoa 41A & 527 & 266 & Supply & UF \\
\hline 282451081054501 & Cocoa 5 & $\mathrm{~b}_{409}$ & 251 & Supply & UF \\
\hline 282457081054601 & Cocoa 6 & 593 & 315 & Destroyed & UF \\
\hline 282530081054201 & Cocoa 7 & $c_{399}$ & 285 & Supply & UF \\
\hline 282529081073201 & Cocoa 7A & 710 & 237 & Supply & UF \\
\hline 282632081054501 & Cocoa 8 & 640 & 255 & Supply & UF \\
\hline 282650081054201 & Cocoa 9 & $\mathrm{~d}_{385}$ & 230 & Supply & UF \\
\hline 282716081054501 & Cocoa 10 & $\mathrm{e}_{350}$ & 229 & Supply & UF \\
\hline 282344081054201 & Cocoa 11 & 580 & 323 & Supply & UF \\
\hline 282412081044701 & Cocoa $12 \mathrm{~A}$ & 600 & 275 & Supply & UF \\
\hline 282404081050501 & Cocoa 12B & 519 & 260 & Supply & UF \\
\hline 282531081075601 & Cocoa 13 & 509 & 244 & Destroyed & UF \\
\hline 282531081075602 & Cocoa 13R & 500 & 240 & Supply & UF \\
\hline 282531081082201 & Cocoa 14 & 761 & 252 & Supply & UF \\
\hline 282530081085401 & Cocoa 15 & 702 & 262 & Supply & UF \\
\hline 282530081091701 & Cocoa 16 & 600 & 255 & Supply & UF \\
\hline 282530081094001 & Cocoa 17 & 600 & 252 & Supply & UF \\
\hline 282556081094001 & Cocoa 18 & 600 & 254 & Supply & UF \\
\hline 282624081090401 & Cocoa 19 & 600 & 254 & Supply & UF \\
\hline 282424081093601 & Cocoa 20 & 602 & 290 & Supply & UF \\
\hline 282406081093601 & Cocoa 21 & 603 & 294 & Supply & UF \\
\hline 282356081091901 & Cocoa 22 & 602 & 293 & Supply & UF \\
\hline 282341081040101 & Cocoa A & 516 & 301 & Monitor & UF \\
\hline 282532081075601 & Cocoa B & 515 & 235 & Monitor & UF \\
\hline 282533081082202 & Cocoa $\mathrm{C}$, zone 1 & 1,357 & 1,351 & Monitor & LF \\
\hline 282533081082204 & Cocoa $\mathrm{C}$, zone 3 & 1,224 & 1,218 & Monitor & LF \\
\hline 282533081082205 & Cocoa $\mathrm{C}$, zone 4 & 1,050 & 1,044 & Monitor & MS \\
\hline 282533081082206 & Cocoa $\mathrm{C}$, zone 5 & 1,004 & 248 & Monitor & UF,MS \\
\hline 282531081095701 & Cocoa D & 300 & 226 & Monitor & UF \\
\hline 282739081054501 & Cocoa F & 357 & 200 & Monitor & UF \\
\hline 282847081013701 & Cocoa $\mathrm{H}$ & 495 & 252 & Monitor & UF \\
\hline 282623081153801 & Cocoa P & 439 & 245 & Monitor & UF \\
\hline 282406081093602 & Cocoa R & 1,205 & 1,098 & Monitor & LF \\
\hline 282531081073001 & Cocoa S & 1,500 & 1,428 & Monitor & LF \\
\hline
\end{tabular}

${ }^{\text {a }}$ Original reported depth $710 \mathrm{ft}$. Plugged to $545 \mathrm{ft}$, and in 1987, to $374 \mathrm{ft}$.

${ }^{\mathrm{b}}$ Plugged from $516 \mathrm{ft}$ in 1984.

${ }^{c}$ Plugged from $490 \mathrm{ft}$ in 1986.

d Plugged from $525 \mathrm{ft}$ in 1985 .

${ }^{\mathrm{e}}$ Plugged from $506 \mathrm{ft}$ in 1986. 


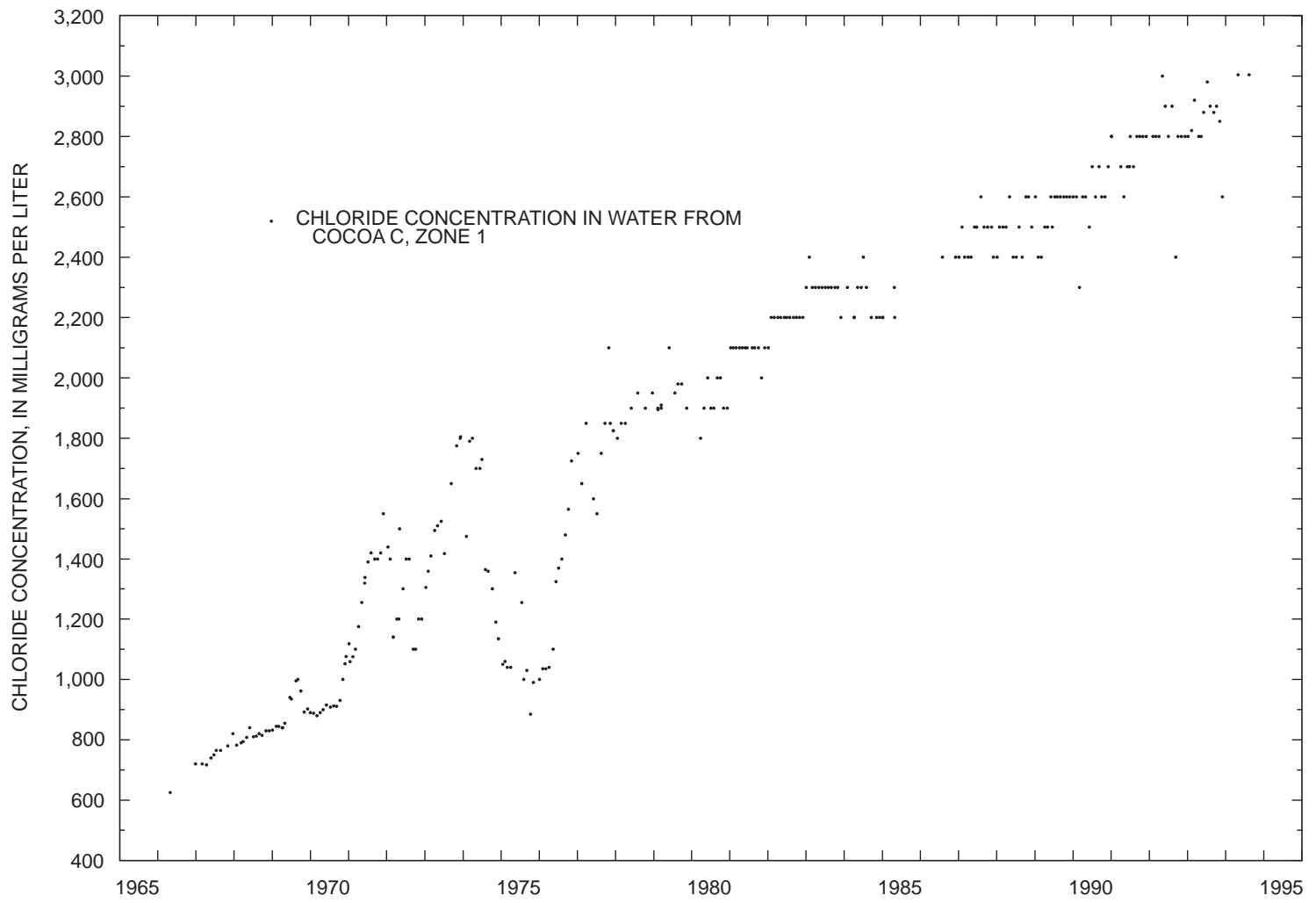

Figure 2. Chloride concentration in water from zone 1 of Cocoa C, 1966-94.

water from these wells (CH2M Hill, 1993). Groundwater flow and solute transport in eastern Orange County, which includes the Cocoa well-field area, were modeled and the results are described in a report by Blandford and Birdie (1992). In that report, the authors concluded that there were insufficient hydraulic and water-quality data for accurate modeling of the Lower Floridan aquifer. Annual data reports produced by the USGS include water-level data from monitored wells in the Cocoa well field and water-quality data (U.S. Geological Survey, 1994). The annual data reports include graphs which show the changes in chloride concentrations in water from the deepest zone in Cocoa C.

\section{Description of Study Area}

The Cocoa well field is located in east Orange County, about $22 \mathrm{mi}$ west of the city of Cocoa. The well-field area primarily consists of pasture land, pine forest, palmetto and scrub brush, and wetlands. Soils in the study area are poorly drained. Most of the surface drainage is through ditches and overland flow to wetlands in the study area. The study area is in the Econlockhatchee River basin.

Mean annual rainfall at the Orlando airport, about $3 \mathrm{mi}$ west of the study area, was $48.11 \mathrm{in}$. during the period 1961-90 (National Oceanic and Atmospheric Administration (NOAA), 1992). Average monthly rainfall is shown in figure 3 . Most of the annual rainfall is during the rainy season (June through September). Rainfall during the rainy season generally occurs in local storms or thunderstorms and can be spatially highly variable. During the dry season (November through May), rainfall results from frontal systems and generally affects large geographic areas. Barometric pressure, which also is measured by NOAA at Orlando, potentially can affect ground-water levels; therefore, barometric-pressure data were obtained for the time periods of the aquifer tests in the Cocoa well field.

\section{Acknowledgments}

The authors would like to thank the employees of the city of Cocoa, especially Gary Heller and Glen Leffler, for their assistance and cooperation during the 


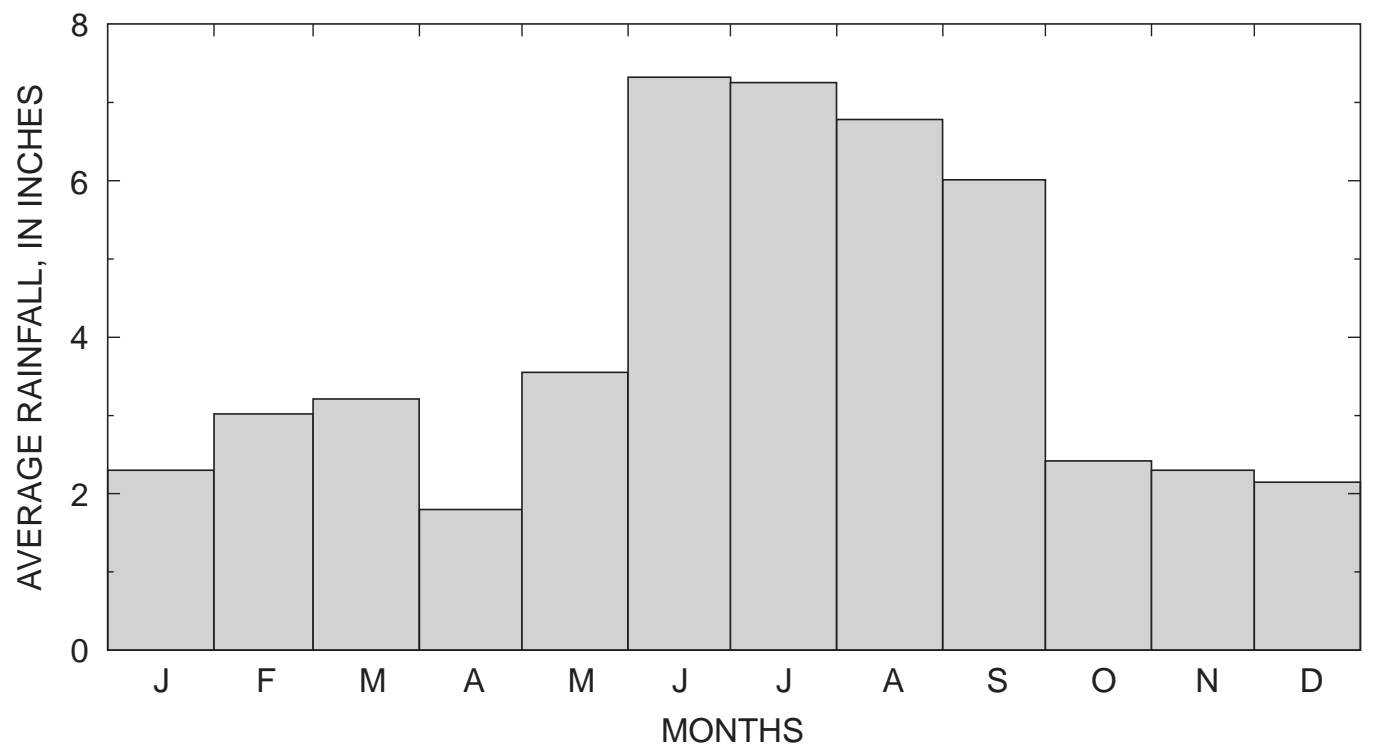

Figure 3. Average monthly rainfall at Orlando, Fla., based on 30 years of record (1961-90, NOAA, 1994).

aquifer tests in the Cocoa well field. The cooperation and information provided by Carl Larabee of the city of Cocoa is also gratefully acknowledged. Robert J. Petersen, CH2M Hill, Gainesville, Florida, provided data from test wells drilled in the Cocoa well field. Numerical analysis of water-level and barometricpressure data was performed by Devin Galloway, USGS, Sacramento, California. The authors are also grateful to John J. Hickey (USGS, Tampa, Florida, retired) for useful discussions about variable-density ground-water flow.

\section{GEOHYDROLOGIC FRAMEWORK}

The geohydrologic units in central Florida (starting at land surface) are the surficial aquifer system, the intermediate confining unit, and the Floridan aquifer system (fig. 4). Beneath the Floridan aquifer system is the sub-Floridan confining unit.

The surficial aquifer system is mostly sand and silty sand with some shell. These surficial sediments are about $40 \mathrm{ft}$ thick in the Cocoa well field. The water table in the surficial aquifer system is nearly always within $10 \mathrm{ft}$ of land surface and is at or within 1-2 ft of land surface in some parts of the Cocoa well field.

Underlying the surficial aquifer system is the intermediate confining unit, from about 40-100 ft below land surface; these sediments generally consist of poorly permeable, fine sand and silt with occasional thin, discontinuous beds of shell (Tibbals and Frazee, 1976) and sediments are Miocene age or younger. Beneath them is the Miocene-age Hawthorn Forma- tion which consists of poorly permeable, clayey sand with occasional thin beds or lenses of shell, limestone, or sand and gravel (Lichtler and others, 1968). The thin beds of shell, sand and gravel, or limestone in the Hawthorn Formation are confined both above and below by less permeable materials and are capable of locally yielding as much as $750 \mathrm{gal} / \mathrm{min}$ to wells (Tibbals and Frazee, 1976, p. 12). Although locally waterbearing, the sediments of the Hawthorn are included in the intermediate confining unit. In the area of the Cocoa well field, the combined thickness of the surficial aquifer system and the intermediate confining unit is about $250 \mathrm{ft}$.

The Floridan aquifer system is the main source of water supply in central Florida and consists of a thick sequence of Eocene-age limestone and dolomite. The hydraulic conductivity of the rocks varies vertically because of differences in lithology. The Floridan aquifer system consists of the following layers: the Upper Floridan aquifer, a middle semi-confining unit, and the Lower Floridan aquifer (fig. 4). At the Cocoa well field, the Upper Floridan aquifer extends from about 250-800 ft below land surface (Tibbals and Frazee, 1976, fig. 3). The middle semi-confining unit extends from a depth of about 800 to about $1,150 \mathrm{ft}$ below land surface. The top of the Lower Floridan aquifer is about $1,150 \mathrm{ft}$ below land surface. The top of the sub-Floridan confining unit is about $2,500 \mathrm{ft}$ below sea level (Miller, 1986, plate 33); at this depth the hydraulic conductivity of the rocks is so low that ground-water flow probably is negligible. 


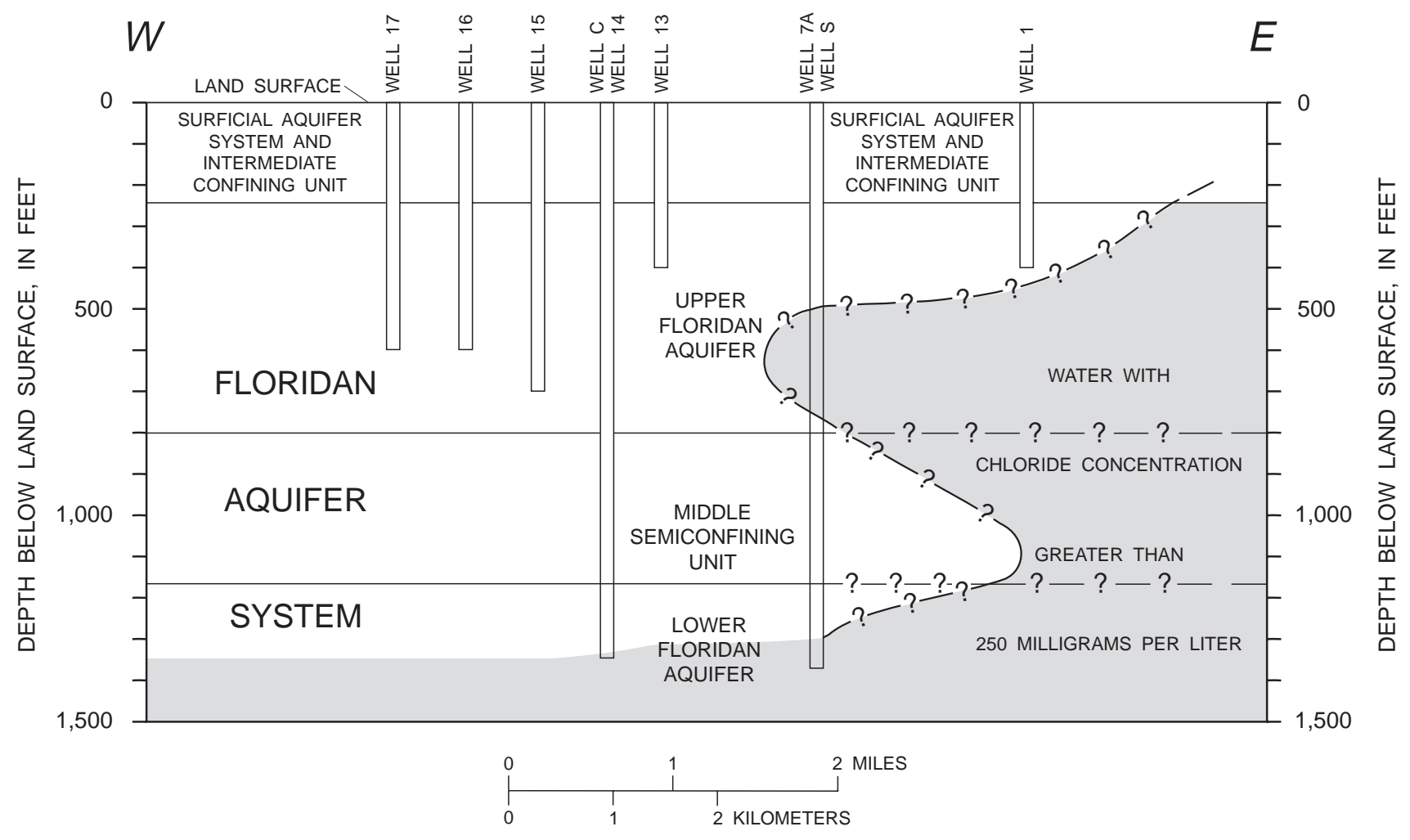

Figure 4. Generalized geohydrologic section in the Cocoa well field.

Geophysical logs of wells in the Cocoa well field indicate that there are zones of lower permeability interspersed through the Upper and Lower Floridan aquifers (fig. 5). Relatively thin zones of higher hydraulic conductivity that produce significant quantities of water also have been noted in the middle semiconfining unit. Monitor wells have been completed to various depths for collection of water-level and waterquality data in several of these zones (fig. 6). Well locations are shown in figure 1 .

The limestone of the Floridan aquifer system generally is very porous. Thayer and Miller (1984) estimated that the porosity of limestone from the Upper Floridan aquifer in central Florida ranges from 15-40 percent, based on thin sections from five samples. The water-bearing capacity of the aquifer system is increased by well-developed solution cavities and channels, both horizontal and, in some areas, vertical. Geophysical logs of wells in the Cocoa well-field area indicate horizontal solution features in all zones of the Floridan aquifer system, the largest of which are in the Upper Floridan aquifer.

The transmissivity of the Upper Floridan aquifer is higher in the old well field (the eastern part) than in the new, western well field. Transmissivity values from aquifer tests reported by Tibbals and Frazee
(1976, table 5) were 74,000 $\mathrm{ft}^{2} / \mathrm{d}$ at well 14 , $510,000 \mathrm{ft}^{2} / \mathrm{d}$ at well $\mathrm{A}$, and $210,000 \mathrm{ft}^{2} / \mathrm{d}$ at well 1 . Transmissivity values from a series of aquifer tests of wells 21, 21, and 22 ranged from 140,000$170,000 \mathrm{ft}^{2} / \mathrm{d}(\mathrm{CH} 2 \mathrm{M}$ Hill, 1993, tables 3-5.) The apparent higher transmissivities in the old well field might also be caused by the presence of fractures in the aquifer.

No evidence of extensive vertical fracturing in the Upper Floridan or the middle semi-confining unit in the area of the Cocoa well field has been observed. However, about $10 \mathrm{mi}$ east of the well field near the St. Johns River, the altitude of the top of the Floridan aquifer system drops abruptly. This structural feature has been identified as a fault (Miller, 1986, plate 8). Recent investigations of similar structural features in the Jacksonville area of northeast Florida (fig. 1) indicate they could be the result of regional collapse of karst features (Spechler, 1994, p. 50-52). Vertical fractures related to the regional structural features apparently influence the local vertical movement of saline water in the Jacksonville area and could have a similar effect in the Cocoa well-field area.

Pumpage from the Upper Floridan aquifer in the Cocoa well field was about 25.6 Mgal/day in 1993 

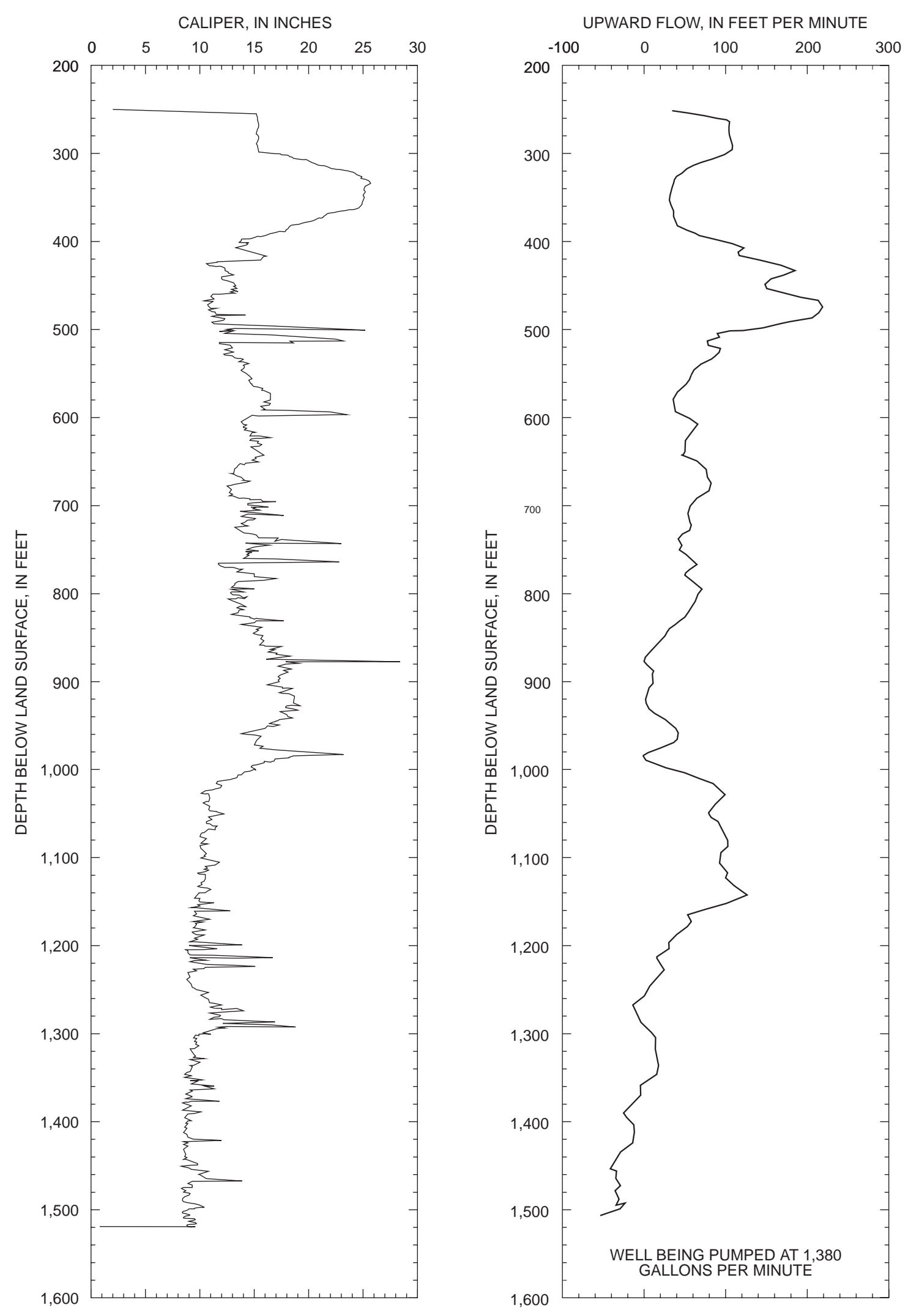

Figure 5. Geophysical logs for well R (data are from CH2M Hill, 1993). 

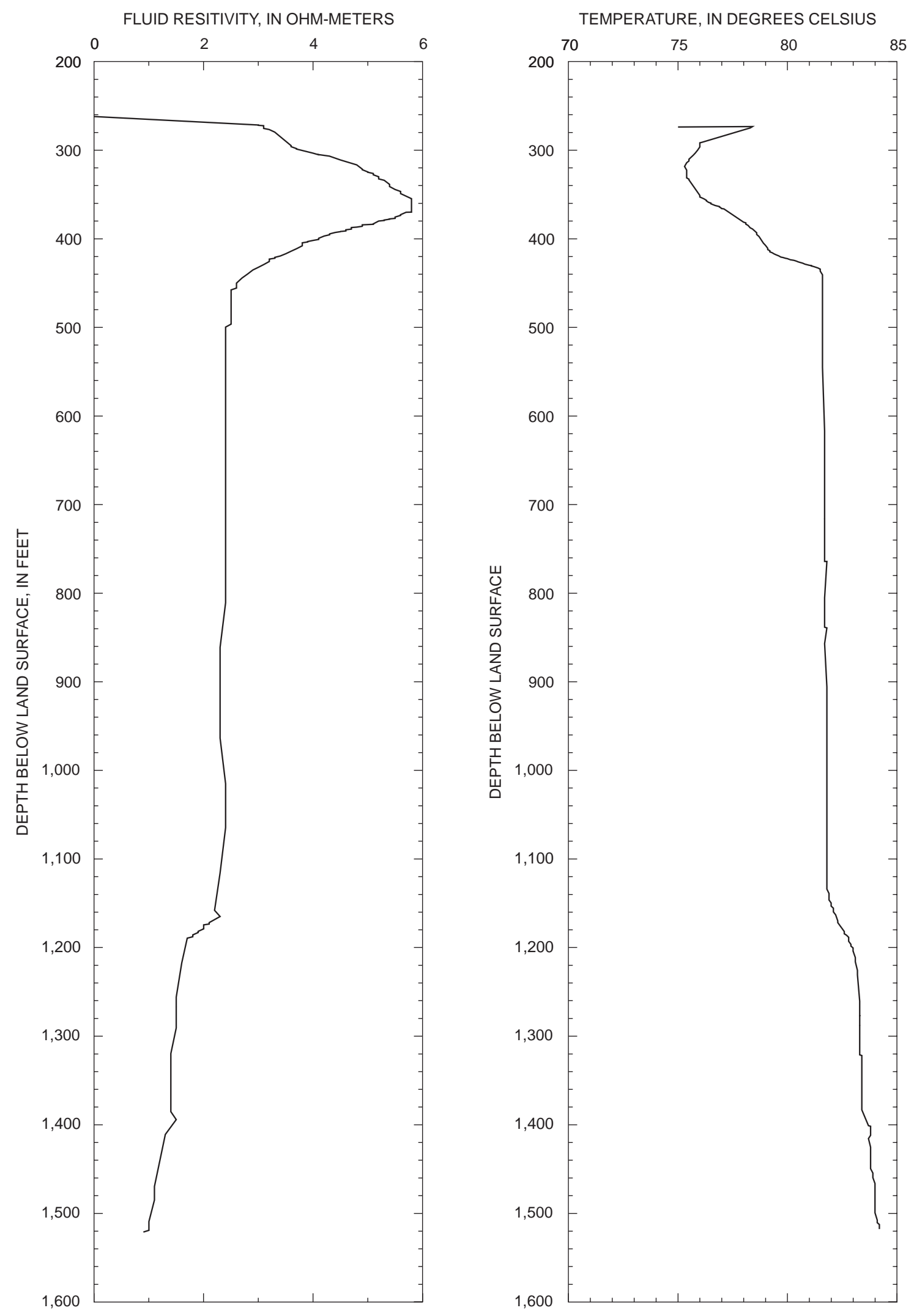

Figure 5. Geophysical logs for well R (data are from CH2M Hill, 1993)—Continued. 

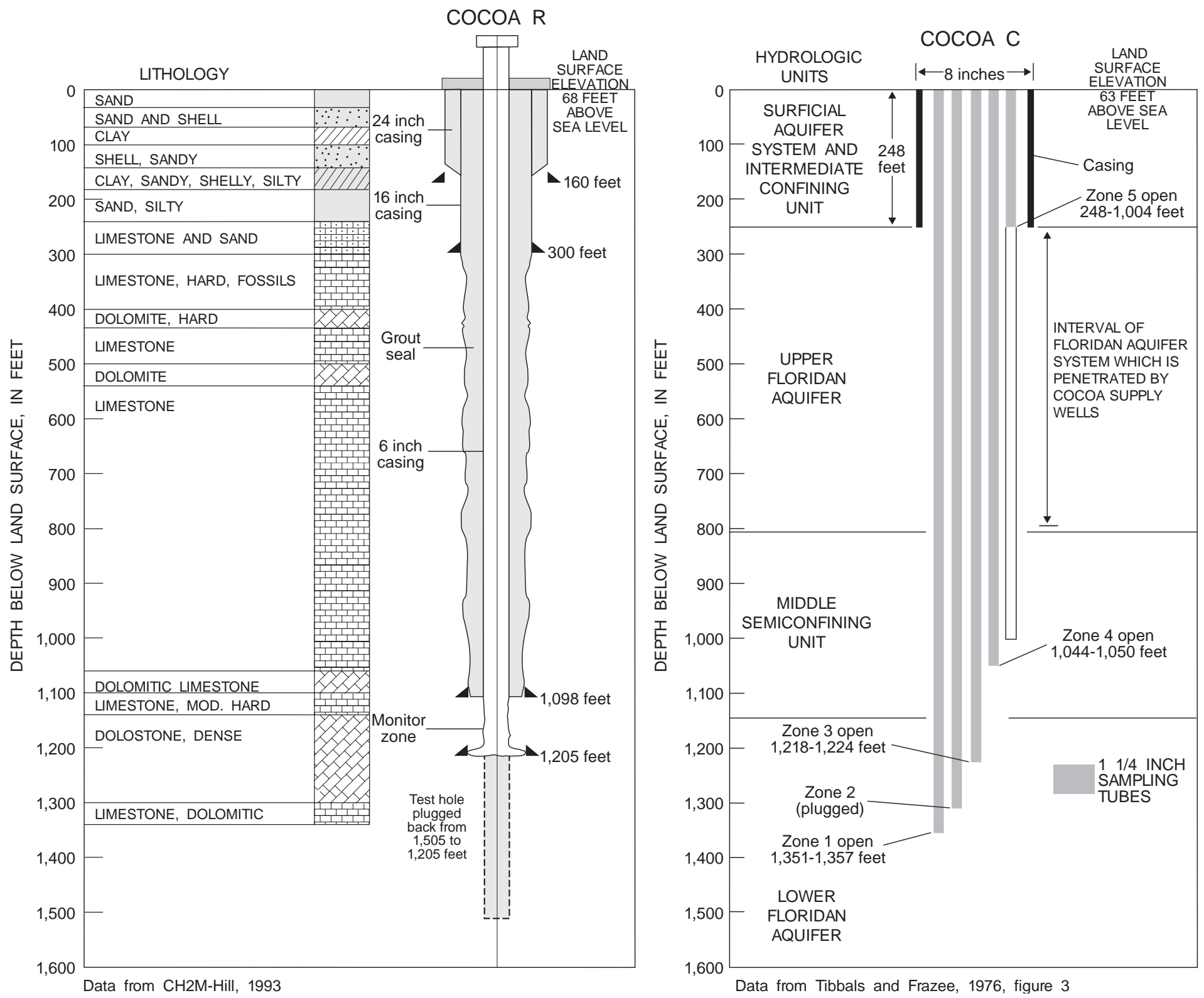

Figure 6. Geohydrologic sections showing well-completion information for wells $\mathrm{C}$ and R. 
(Gary Heller, city of Cocoa, oral commun., 1994). In the Orlando area, about $15 \mathrm{mi}$ west of the Cocoa well field, water is withdrawn from the Upper and Lower Floridan aquifers. Estimated pumpage in the Orlando area in 1995 is about $60 \mathrm{Mgal} / \mathrm{d}$ from the Upper Floridan aquifer and about $56 \mathrm{Mgal} / \mathrm{d}$ from the Lower Floridan aquifer.

The regional direction of ground-water flow in the Upper Floridan aquifer is from west to east in the general area of the Cocoa well field, except in localized areas affected by pumping wells (fig. 7). The altitude of the potentiometric surface of the Upper Floridan aquifer usually fluctuates seasonally about $5 \mathrm{ft}$ in the area of the well field, based on records for 1960-95. The altitude of the potentiometric surface in the well-field area was about $35 \mathrm{ft}$ in September 1993 and also in May 1994 after a relatively wet winter. This altitude is about $10 \mathrm{ft}$ lower than the potentiometric-surface altitude measured in 1961 (Healy, 1962). Some of the decline in the potentiometric-surface altitude can be attributed to increased pumping in the area, but part of the difference between the 1961 potentiometric-surface altitude and the altitude in more recent years might be due to climatic variations. Rainfall was abundant during the early 1960's; the record maximum for rainfall in Orlando was $68.74 \mathrm{in}$. in 1960. However, the 1970's and 1980's were drier. From 1970-85 there was a cumulative deficit of rainfall at Orlando of about 35 in. From 1986-94, a cumulative surplus of about 32 in. was recorded for Orlando. Much of the surplus rainfall during this period was a result of rainfall in 1994, which was

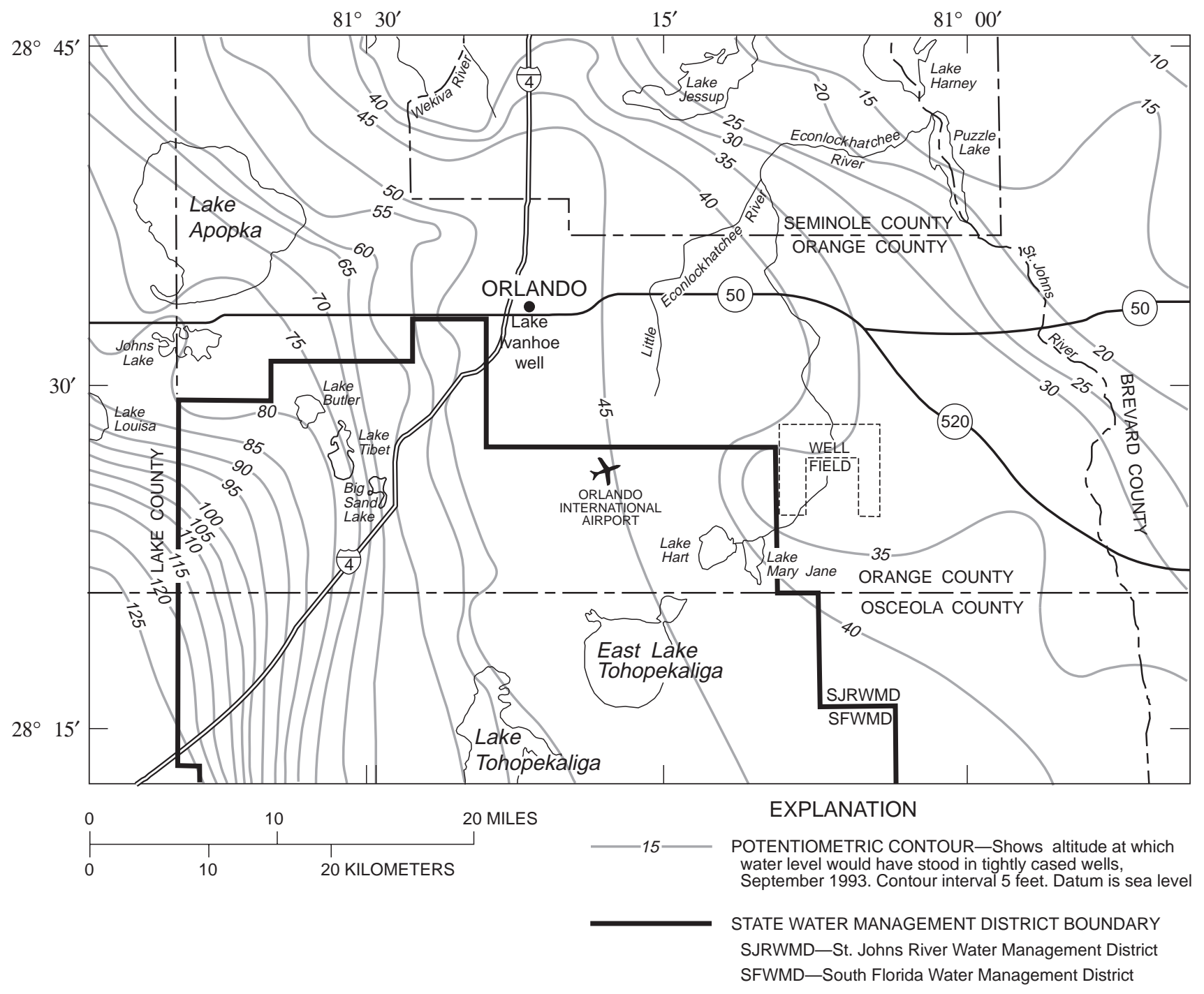

Figure 7. Potentiometric surface of the Upper Floridan aquifer in the vicinity of the Cocoa well field, September 1993. 
67.85 in., 19.74 in. above the 30 -year mean annual rainfall for 1961-90, 48.11 in. The potentiometricsurface altitude in the well-field area rose to about $40 \mathrm{ft}$ in September 1994.

Water levels in the Cocoa well field generally decrease with depth (Tibbals and Frazee, 1976, p. 12). The water table is at or near land surface. Water levels in wells penetrating the Hawthorn Formation part of the intermediate confining unit fluctuate from about 10-20 ft below land surface; the potentiometric surface of the Upper Floridan aquifer is about $35 \mathrm{ft}$ below land surface and is affected by pumping from the aquifer. Water levels in the middle semi-confining unit and the Lower Floridan aquifer (measured in zones 4 and 3 of Cocoa C) were about $30 \mathrm{ft}$ below land surface in August 1993.

\section{CHLORIDE CONCENTRATIONS IN GROUND WATER}

The chloride concentration in the water of the Upper Floridan aquifer in Orange County generally increases from west to east (fig. 8). Chloride concentrations are less than $50 \mathrm{mg} / \mathrm{L}$ throughout most of the western part of the county, but increase abruptly toward the St. Johns River to the east. No wells in east Orange County directly east of the Cocoa well field (and west of the St. Johns River) have been sampled since 1972, but the Brevard County Water Resources Department regularly samples wells just east of the St. Johns River. The chloride concentration in water from well 282204080514301 was $6,000 \mathrm{mg} / \mathrm{L}$ in 1994 , and from well 283236080535101 (fig. 8) was $2,330 \mathrm{mg} / \mathrm{L}$

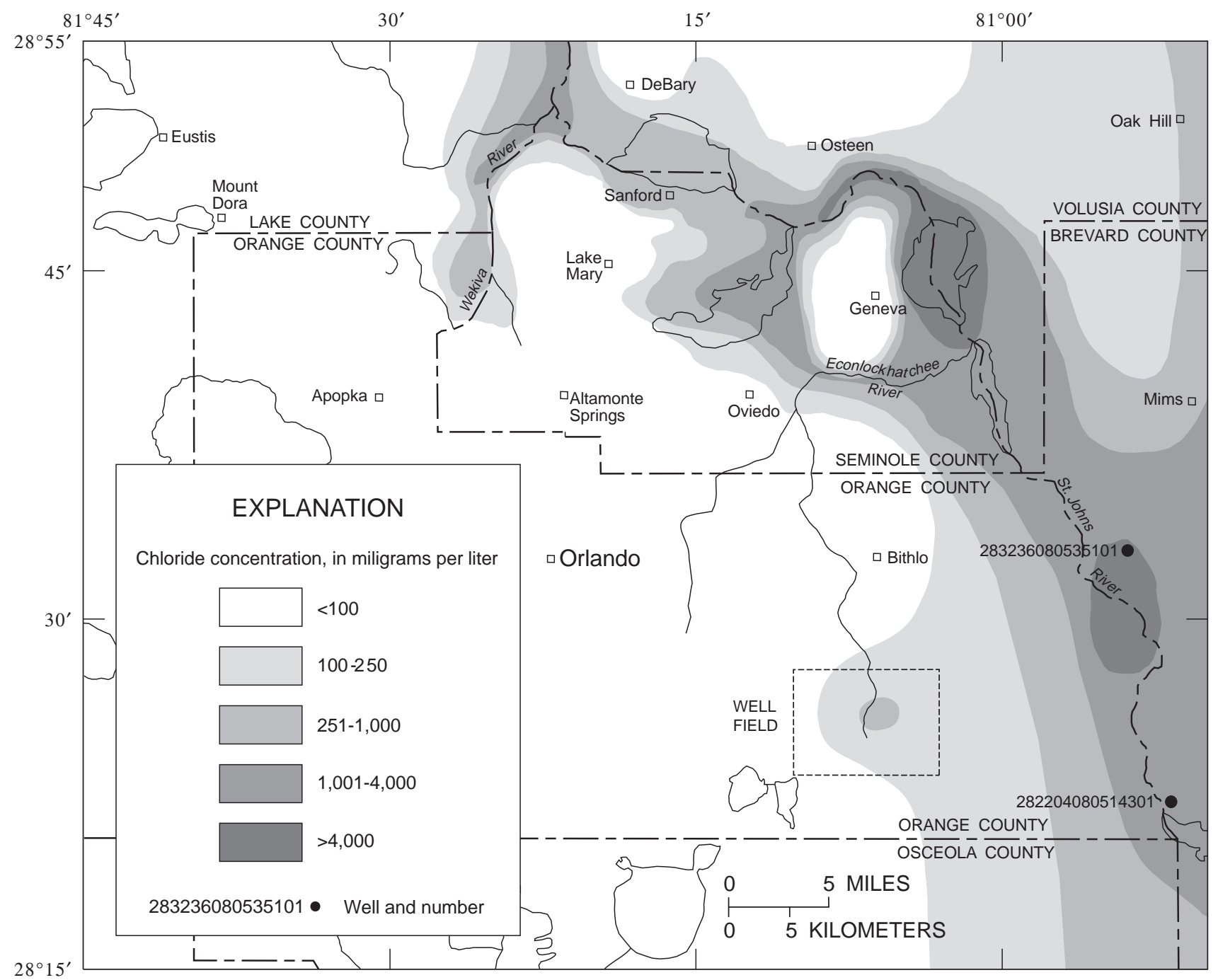

Figure 8. Chloride concentration in water from the Upper Floridan aquifer, Orange County, Fla., and vicinity. (Data from L.C. Murray, Jr., USGS, written commun., 1994, and W. Boggs, Brevard County, written commun., 1995). 
(W. Boggs, Brevard County Water Resources Department, written commun., 1995). The saline water in the Floridan aquifer system is relict seawater which remained after the sea level rose and fell repeatedly during Pleistocene glaciation, rather than modern seawater encroaching from the Atlantic Ocean (Lichtler and others, 1968, p. 127). For this reason, the distribution of saline water in the Floridan aquifer system is heterogeneous and saline and fresher water probably interfinger within the aquifer.

Monitor well C was drilled in 1965 for collection of water samples from specific zones of the Floridan aquifer system in the Cocoa well field. These zones are: zone $1(1,351-1,357 \mathrm{ft})$, zone 3 (1,218$1,224 \mathrm{ft})$, zone $4(1,044-1,050 \mathrm{ft})$, and zone 5 , which is open from the 248 -ft depth surface casing of the well to a depth of 1,004 ft. Zone 5 is used to monitor the water-supply zone. Water level and water-quality data have been collected for well C since 1966. Monitor well R, completed in 1991, is about 2 mi southwest of well $\mathrm{C}$ and is open from 1,098-1,205 ft below land surface. Well completion information for wells $\mathrm{C}$ and $\mathrm{R}$ is shown in figure 6.
Monthly water samples from the monitor wells and from about 20 other wells in the Cocoa well field are collected and analyzed for chloride concentration. Long-term records indicate that chloride concentrations are increasing in many wells (figs. 9 and 10). In well $\mathrm{C}$, chloride concentrations have increased in zone 1 (the deepest zone) and in zone 5 (the pumped zone), but stayed about the same in zones 3 and 4 (fig. 10). The chloride concentration in water from zone 3 (open from 1,218-1,224 ft below land surface) is about $80 \mathrm{mg} / \mathrm{L}$, and the concentration is about $40 \mathrm{mg} / \mathrm{L}$ in the shallower $(1,044-1,050 \mathrm{ft})$ zone 4 .

Generally, the wells in the eastern part of the well field produce water with higher chloride concentrations than wells in the western part. The sudden drop in chloride concentration in water from well 13 (fig. 9) resulted when the original well 13 was plugged because of casing problems and replaced by a well of similar depth (13R) which is pumped at a lower rate. Chloride concentrations in water from well $13 \mathrm{R}$ also have increased. Well depths are shown in table 1.

Monitor well S was drilled in July-August 1994 near well 7A (fig. 1). Drill-stem chloride data from

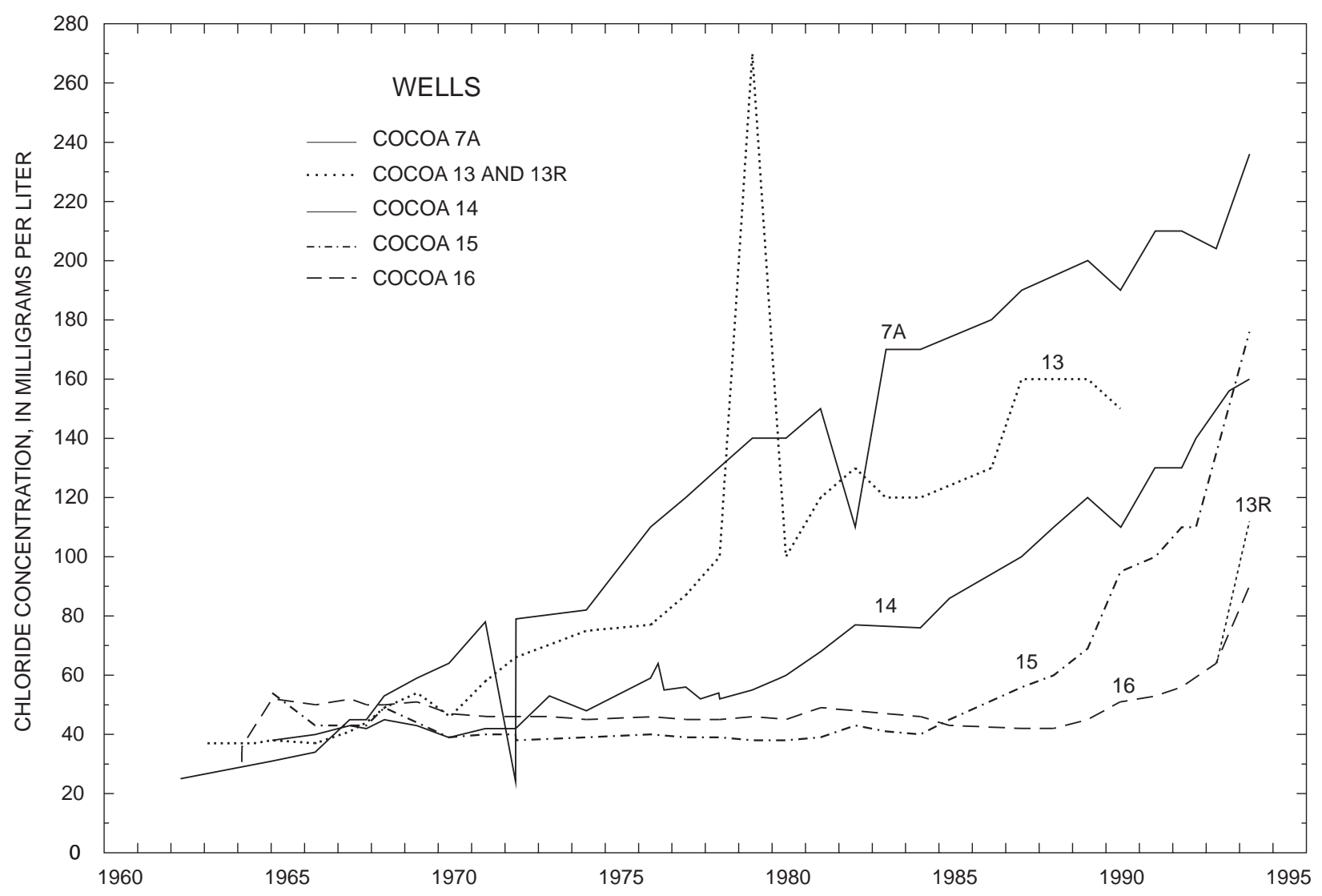

Figure 9. Chloride concentrations in water from selected wells in the Cocoa well field, 1960-94. 

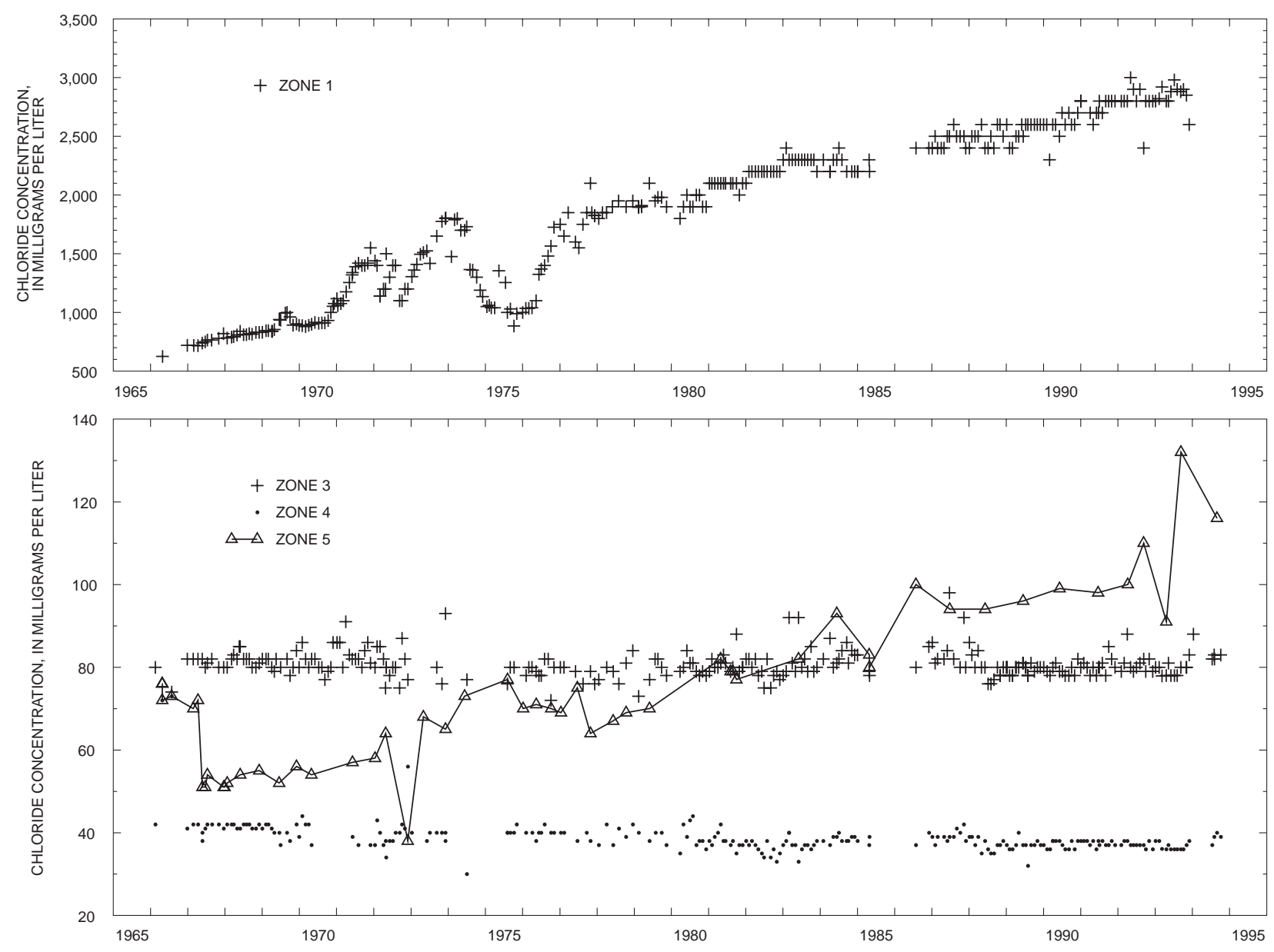

Figure 10. Chloride concentrations in water from zones of well C, 1966-94.

Cocoa S (R.J. Petersen, CH2M Hill, written commun., 1994), shown in figure 11 , indicate that from depths of about 450-1,000 ft, chloride concentrations are higher at well $\mathrm{S}$ than at well $\mathrm{R}$, which follows the observed pattern of decreasing chloride concentration toward the west. In the interval from about 1,000-1,180 ft, chloride concentrations are about the same in both wells. This interval intersects a zone of low hydraulic conductivity, based on the geophysical logs of well $\mathrm{R}$ (fig. 5). Chloride concentrations increase sharply in water from both wells at depths of about $1,200-1,380 \mathrm{ft}$ (from about $100 \mathrm{mg} / \mathrm{L}$ to about $500-600 \mathrm{mg} / \mathrm{L}$ ) and again below about 1,380 ft. Chloride concentrations in well S increased from about $5,000 \mathrm{mg} / \mathrm{L}$ at a depth of about $1,480 \mathrm{ft}$ to about $10,000 \mathrm{mg} / \mathrm{L}$ at a depth of $1,560 \mathrm{ft}$, the maximum test-drilling depth (fig. 12). These data indicate that the depth interval of zone 1 of monitor well $\mathrm{C}(1,351-1,357 \mathrm{ft})$ is just above the abrupt increase in chloride concentration.
Concentrations of chloride as a function of depth for other wells in the well field were compared with concentrations for wells R and S (fig. 11). Chloride concentrations in water from well 4 (depth $524 \mathrm{ft}$ ) and well 11 (depth $580 \mathrm{ft}$ ) in the southeast part of the well field are similar to concentrations in water from the same respective depths in wells $\mathrm{R}$ and $\mathrm{S}$. Further north, in the area of well 1 (depth $374 \mathrm{ft}$ ), well 3 (depth $374 \mathrm{ft}$ ), and well 9 (depth $385 \mathrm{ft}$ ), the chloride concentration apparently increases more rapidly with depth.

Well 1 originally was drilled to a depth of $1,287 \mathrm{ft}$. After the well was plugged to a depth of $710 \mathrm{ft}$, a water sample collected from that depth in 1964 had a chloride concentration of $740 \mathrm{mg} / \mathrm{L}$. Subsequently, the well was plugged back to a depth of $374 \mathrm{ft}$; a water sample collected after plugging had a chloride concentration of $96 \mathrm{mg} / \mathrm{L}$ in 1994. Assuming that the chloride increase with depth in well 1 is linear, the chloride concentration in water from well 8 (which 
had the highest concentration of all the wells sampled in 1994) is comparable to the chloride concentration expected at the same depth in well 1 . If saline water were leaking through the plug in well 1 , wells 1,7 , and 8 would be likely to produce water with higher chloride concentrations than observed. Instead, the chloride concentrations in water from well 9 are slightly greater and from well 3 much greater than expected for the depths of the wells. The variation of chloride concentration with depth from one part of the well field to another indicates that the movement of saline water in the Upper Floridan aquifer in the area of the well field is complex and probably related to a heterogeneous distribution of water with higher chloride concentration in the aquifer.

\section{WATER LEVELS}

Water levels have been measured regularly in the Cocoa well field since the 1960's. Some wells are measured continuously and about 20 wells are measured monthly. Water levels are measured in wells tapping the surficial aquifer system, the intermediate confining unit, and the Upper Floridan aquifer. Monitor wells $\mathrm{C}$ and $\mathrm{R}$ provide information about water levels in the Lower Floridan aquifer. Upper Floridan aquifer water levels also are measured continuously at the observation well Bithlo 1, about $5 \mathrm{mi}$ north of the well field (fig. 1).

\section{Factors Affecting Water Levels}

Hydrographs of ground-water levels in the Cocoa well field and at Bithlo were analyzed during this study. In addition to the effects of pumping and variations in the amount of ground-water recharge from rainfall, water levels can be affected by changes in barometric pressure and by differences in the density of the water measured, which are discussed in the following sections.

\section{Barometric Pressure and Tidal Effects}

The water levels in wells tapping confined aquifers are influenced by variations in barometric pressure and by the effects of ocean and earth tides.

Barometric pressure fluctuates diurnally in response to the heating of the atmosphere by solar radiation and subsequent cooling of the atmosphere at night. These barometric fluctuations occur globally throughout the year, during every season. Of the two daily cycles, the night-time pressure fluctuations usually are of greater magnitude. The cycles of pressure maxima and minima are regularly spaced and do not precess with time. Fluctuations caused by the dilation of the earth due to the position of the moon (earth tide effects) precess with time just as the ocean tides do, thus, making it possible to separate the effects of barometric pressure changes from the effects of earth tides.

Water levels in wells Bithlo 1 and Cocoa $\mathrm{R}$ for the period November 12-19, 1993, are shown in figure 13 . The regularly spaced water-level fluctuations are indicative of the effects of barometric pressure. Barometric-pressure fluctuations (National Weather Service in Orlando, written commun., 1994) and the water levels in well $\mathrm{R}$ in the Cocoa well field for the period January 20-February 15, 1994, are shown in figure 14 . The diurnal fluctuations are evident in the graph and a more gradual trend of increasing water level is shown as the barometric pressure gradually decreases (for example, from January 20 to January 30).

The water-level data for Cocoa $\mathrm{R}$ were processed using digital filters to remove unwanted high and low frequency components so that the barometric pressure and tidal effects could be investigated (Devin Galloway, U.S. Geological Survey, written commun., 1994). The analysis indicates that both barometric pressure and the effects of earth and ocean tides influence water levels in well $\mathrm{R}$ and probably in well $\mathrm{C}$ also. However, because other factors apparently are affecting the water levels in the same frequency range as the barometric pressure effects, it was not possible to separate the effects of the two. For this reason, the barometric efficiency of the aquifer, which is the ratio of the change in hydraulic head to the change in barometric pressure (Freeze and Cherry, 1979, p. 233-234), could not be determined.

\section{Density Differences}

Total hydraulic head, as measured by water levels, is partly dependent on water density. Water from the Upper Floridan aquifer is fresh and is of approximately uniform density. However, in the Lower Floridan aquifer the dissolved solids concentration, and thus density, increases with depth. Because of the density difference, measured water levels in the Upper and Lower Floridan aquifers cannot be directly compared. 


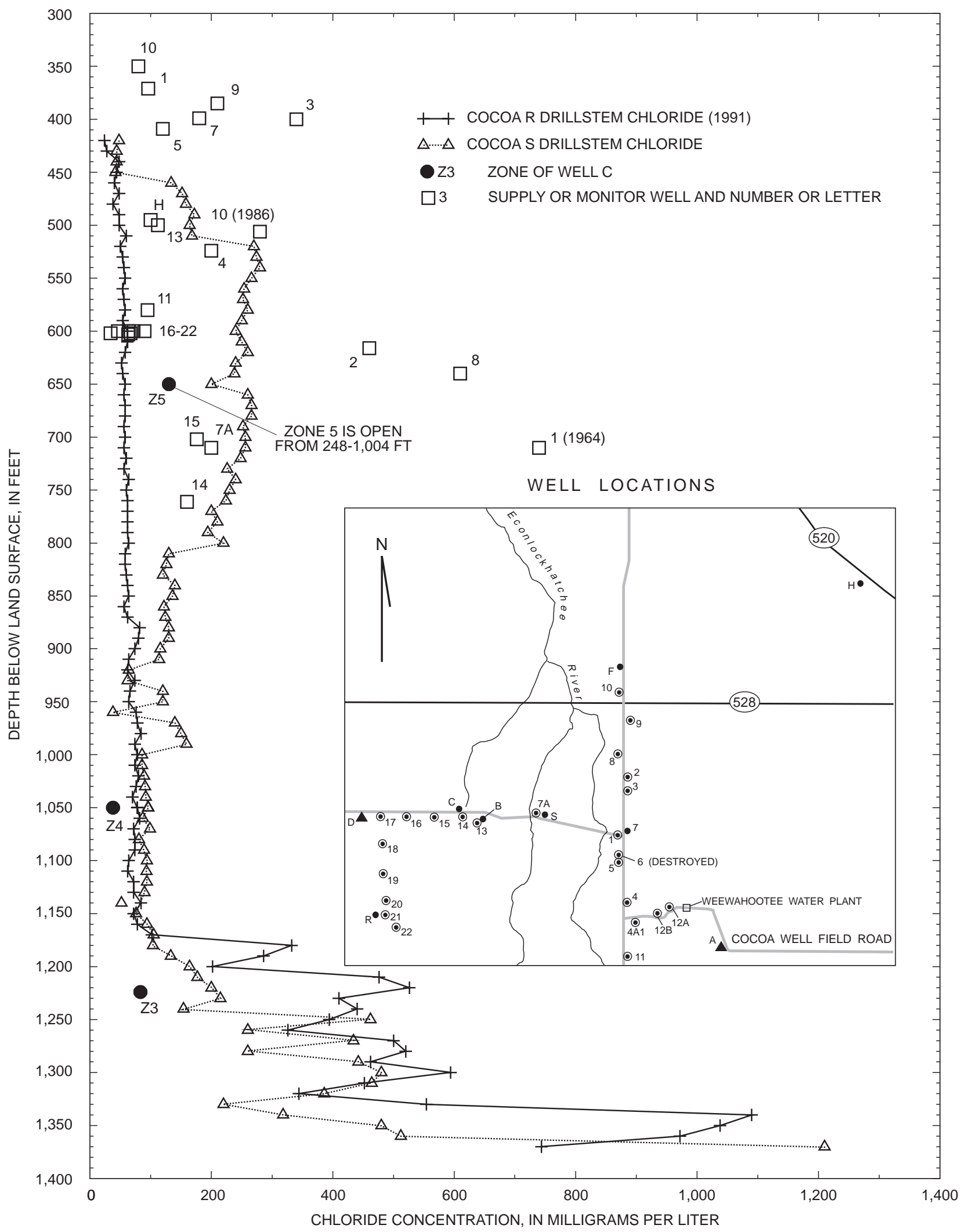

Figure 11. Relation of chloride concentration and depth in selected wells. (Drillstem data are from $\mathrm{CH} 2 \mathrm{M} \mathrm{Hill.} \mathrm{Data} \mathrm{are}$ from 1994 unless othewise noted. Land-surface altitudes at wells range from 63-75 ft. 


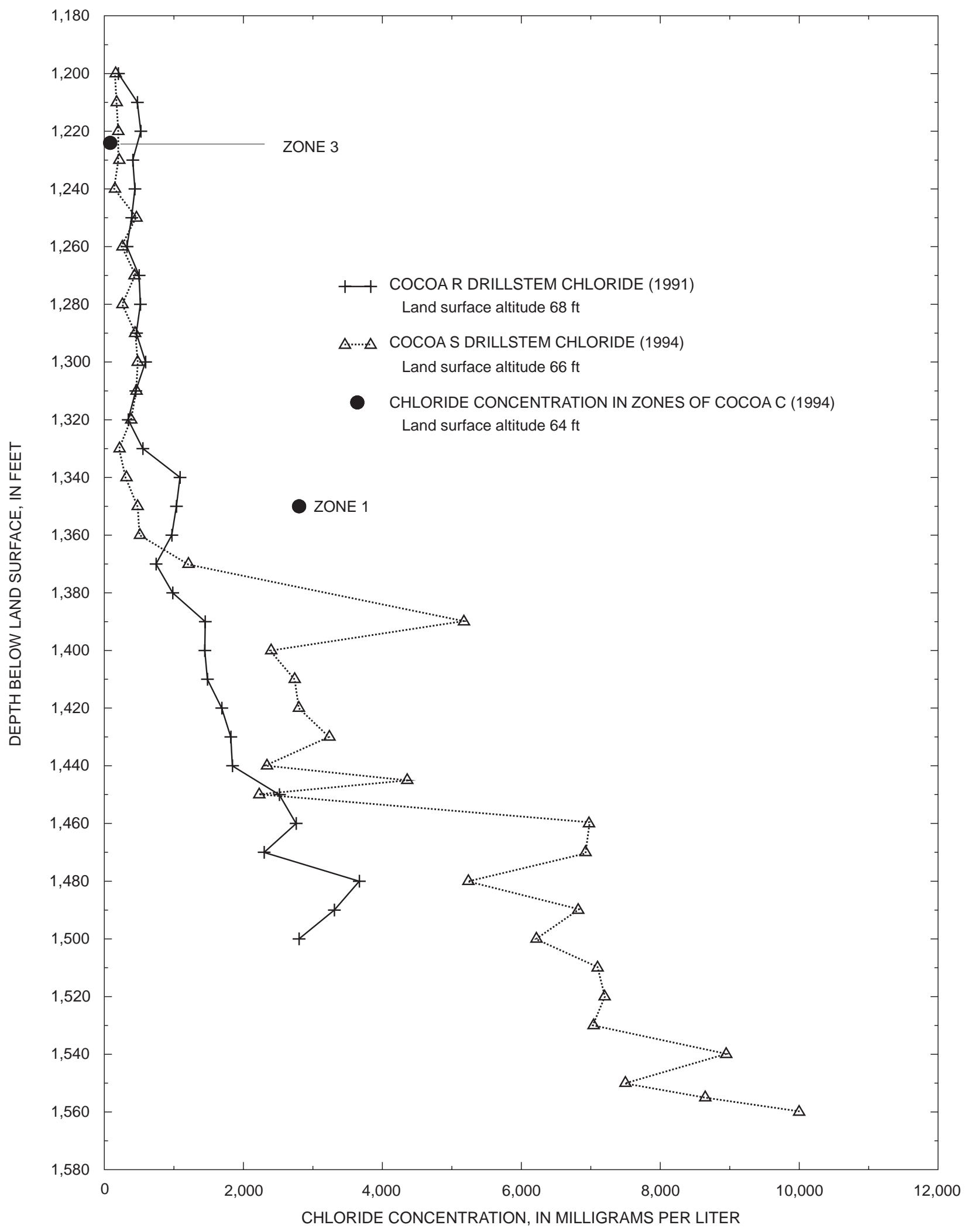

Figure 12. Relation of chloride concentration and depth in parts of wells $C, R$, and $S$. 

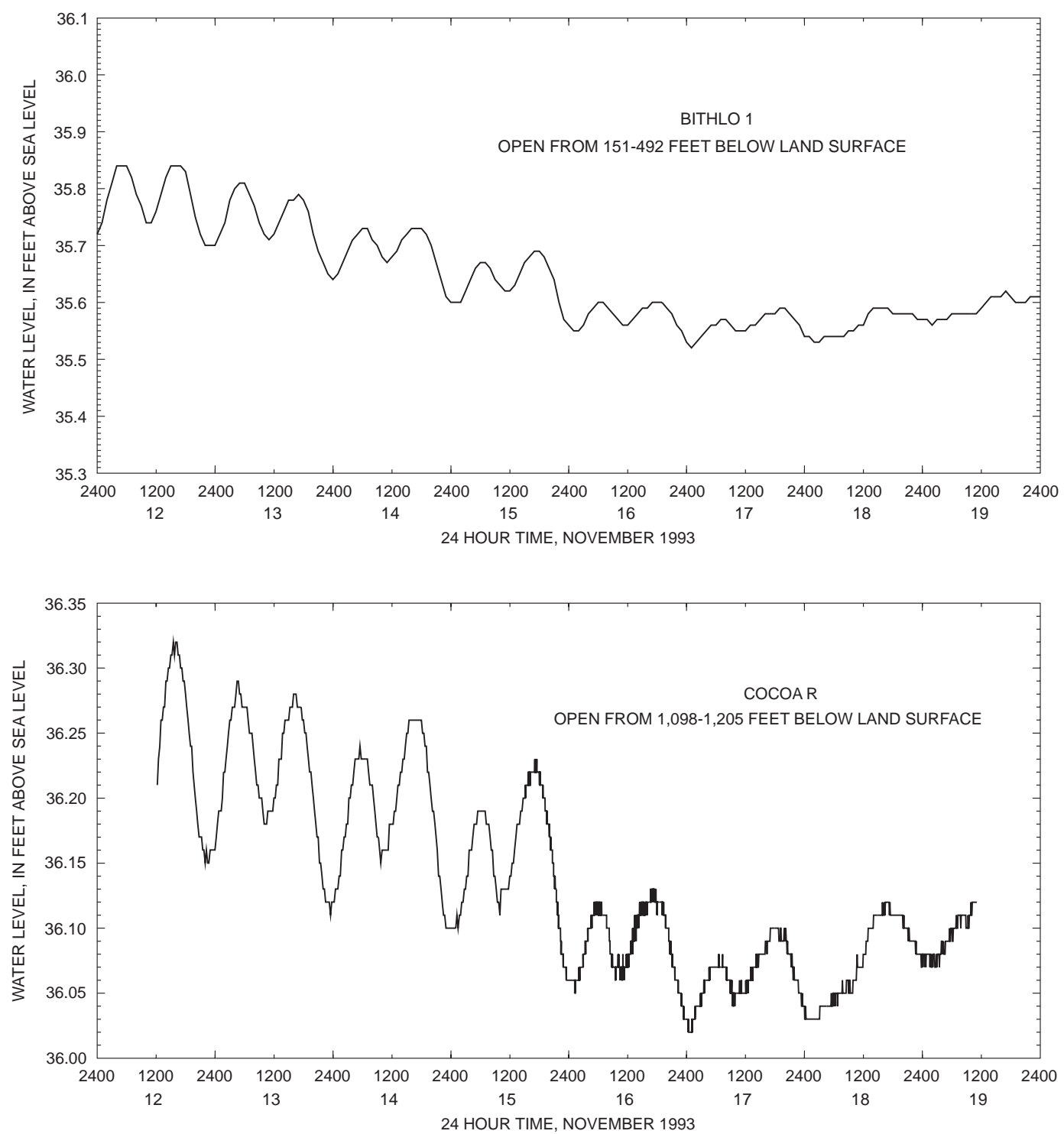

Figure 13. Water levels in well 1 at Bithlo, Fla., and Cocoa R, November 12-19, 1993.

The relation between water density and water level (hydraulic head) was described by Lusczynski (1961). He defined the water at any point in an aquifer containing water of variable density as point water, which may be fresh, salt, or mixed (diffused) water. Point-water head is the elevation (referred to a given datum) to which the water level in a well would rise if the well were filled with water of the same density as at the point of interest in the aquifer (fig. 15). For example, if all the water in a water column is fresh, then the hydraulic head or water level measured in the well is a freshwater head, and also is the point-water head for the point in the aquifer where the head is measured. Water levels measured in zones 3, 4, and 5 of well $\mathrm{C}$ are freshwater heads and also are pointwater heads for the respective zones.

The water levels measured in zone 1 of well $\mathrm{C}$ are point-water heads for that zone but are not directly comparable to the point-water heads measured in the freshwater zones of well $\mathrm{C}$ because the zone 1 water column is filled with saline water. The point-water heads in the saline-water zone could be converted to equivalent freshwater heads (the water levels that would be measured if the water column were filled with freshwater instead of saline water) to eliminate the effects of increasing water density with time in 


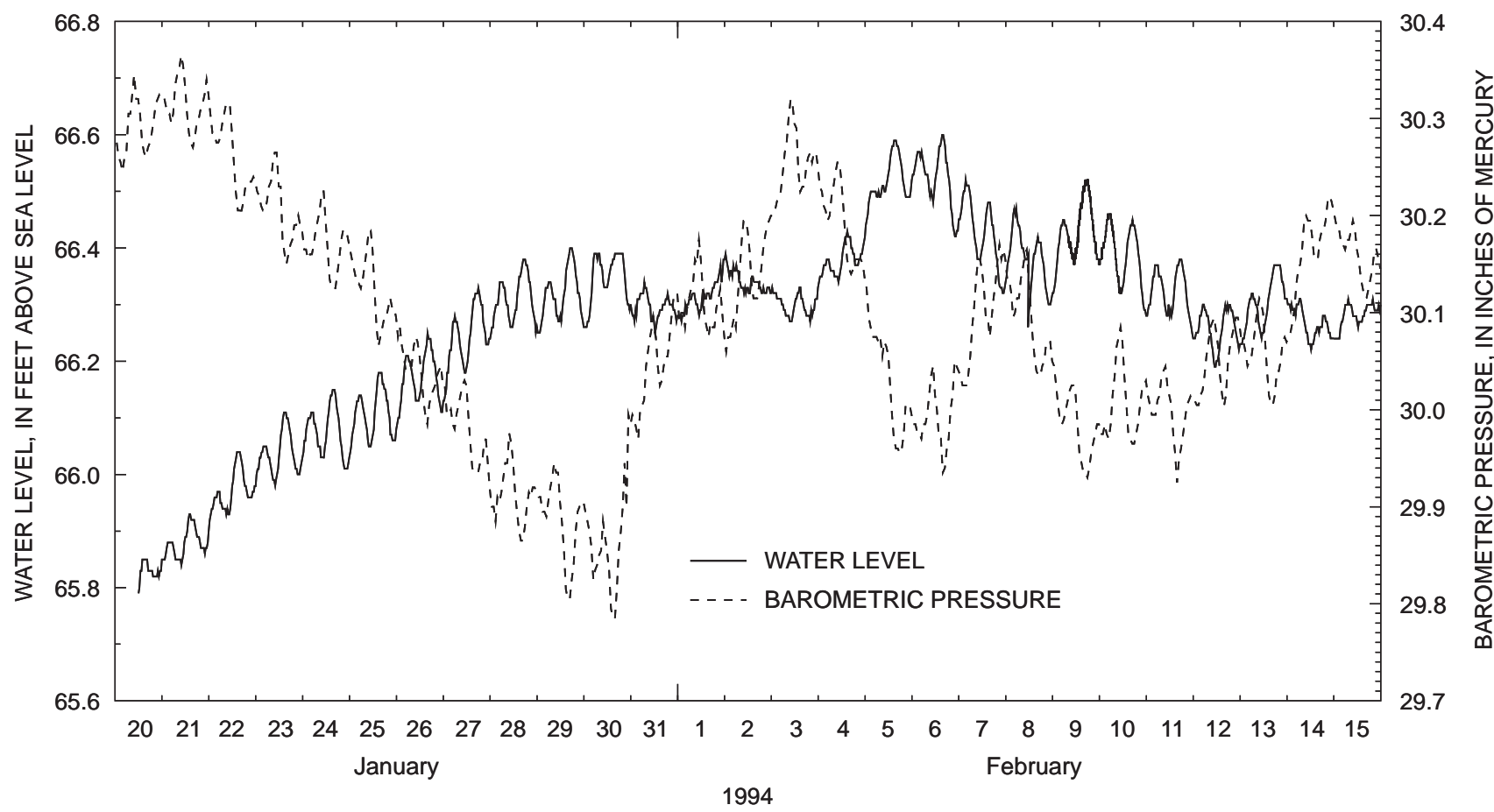

Figure 14. Water levels in well $\mathrm{R}$ and barometric pressure, January 20-February 15, 1994.

zone 1. The equivalent freshwater head can be calculated using an equation from Reilly (1993, equation 18-26):

$$
h_{f}=z+\frac{\rho_{w}}{\rho_{f}} l
$$

where:

$h_{f}$ is equivalent freshwater head, in feet, $z$ is the elevation above (or below) a datum of the point representing the well screen, in feet,

$l$ is the height of the water in the well, in feet, and $\rho_{w}$ and $\rho_{f}$ are the densities of the water in the well and of freshwater, respectively.

Lusczynski (1961) recognized that equivalent freshwater heads cannot be used to determine the vertical hydraulic gradient in an aquifer with water of non-uniform density. He defined environmental head as the head that would be measured in a well filled with freshwater in the freshwater part of the aquifer, and filled with mixed or saltwater in the parts of the well that penetrate mixed or saltwater parts of the aquifer (fig.15). Because environmental-water heads define hydraulic gradients along a vertical, they are comparable along a vertical (Lusczynski, 1961, p. 4249).

\section{Trends in Long-Term Water Levels}

Water levels in the Upper Floridan aquifer in the Cocoa well-field area have declined through time. Before pumping from the Floridan aquifer system in central Florida began in the early 1900's, the water level in the Upper Floridan aquifer was about $50 \mathrm{ft}$ above sea level in the area of the Cocoa well field (Tibbals, 1990, fig. 20). On February 2, 1994, when there was no nearby pumping in the well field, the water level in well $\mathrm{C}$, zone 5 , was $36.81 \mathrm{ft}$ above sea level, a decline of about $13 \mathrm{ft}$ from predevelopment conditions. Pumping well 14 (about $180 \mathrm{ft}$ away from well $\mathrm{C}$ ) causes the water level in zone 5 to decline about 4-5 ft.

No predevelopment water levels are available for the lower zones of the aquifer; however, because the well-field area is in a recharge area, the water levels in the Lower Floridan aquifer probably were lower than those in the Upper Floridan aquifer. By the time well C was drilled in 1966, water levels in the Upper Floridan aquifer had been lowered by pumping so that water levels in zone 5 were lower than those in zones 3 

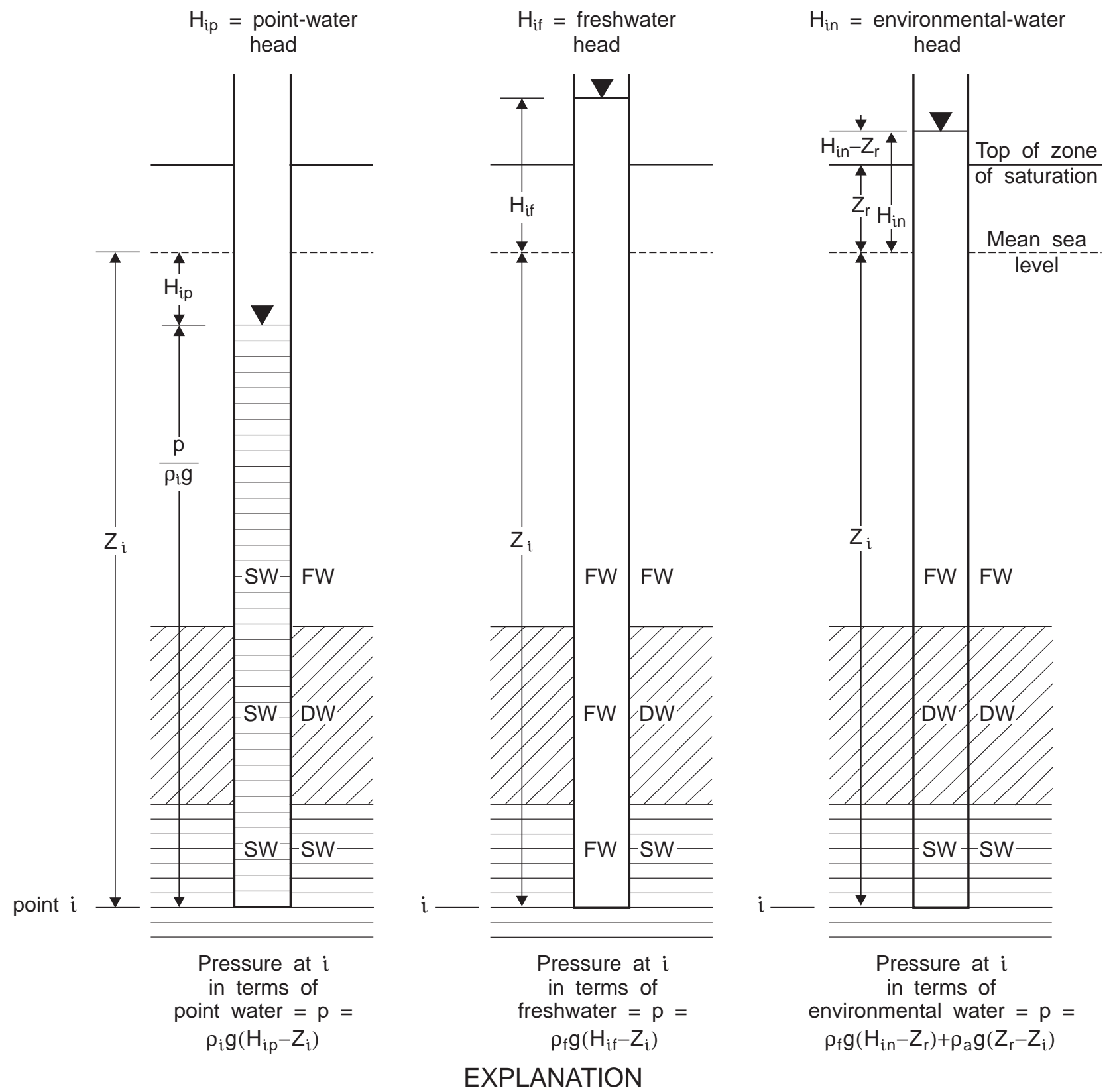

$\begin{array}{lllll}\text { FW } & \text { Freshwater } & g & \text { Acceleration of gravity } & \rho_{i} \\ \text { DW } & \text { Diffused water } & Z_{i} & \text { Altitude at point } i & \rho_{f} \\ \text { SW } & \text { Saltwater } & Z_{r} & \text { Altitude of a reference point } & \rho_{a}\end{array}$

$\rho_{i} \quad$ Mass density of water at point $i$

$\rho_{f} \quad$ Mass density of freshwater

$\rho_{\mathrm{a}} \quad$ Average mass density of water between points $Z_{r}$ and $Z_{i}$

Figure 15. Definitions of point-water, freshwater, and environmental-water heads in ground water with variable density (from Lusczynski, 1961).

and 4 of well $\mathrm{C}$. The water level in zone 4 is usually about $0.1 \mathrm{ft}$ higher than the level in zone 3 .

Water levels in zones 3,4 , and 5 of well $\mathrm{C}$ are not directly comparable with water levels in zone 1 because the water in zone 1 has a higher density than water in the overlying zones. However, equivalent freshwater heads can be compared among zones. Both point-water and equivalent freshwater heads for zone 1 (calculated using equation 1) are shown in figure 16. The equivalent freshwater head in zone 1 usually is lower than the head in zone 3. Much of the apparent decline in the pointwater head in zone 1 after 1970 can be attributed to the increase in density of water in that zone as chloride concentrations increased (fig. 2), but 

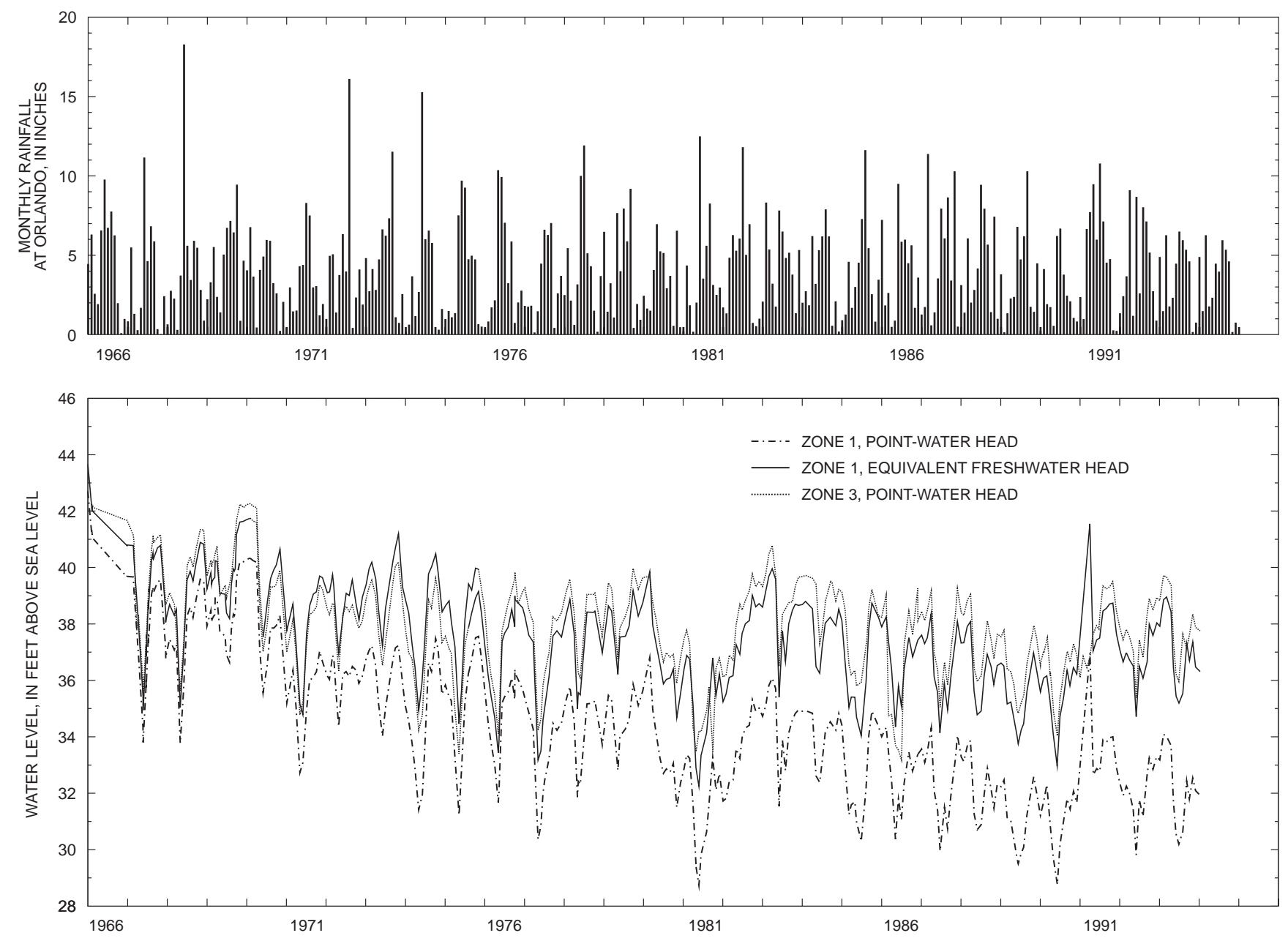

Figure 16. Point-water heads in zones 1 and 3 of well $C$, equivalent freshwater head in zone 1 , and monthly rainfall at Orlando, Fla., 1966-94.

the declines in all zones probably are primarily caused by pumping from both the Upper and Lower Floridan aquifers.

Water levels in observation well Bithlo 1, which apparently is not affected by pumping, are shown in figure 17 along with water levels for zones 3,4 , and 5 of well C. Rainfall deficits totaling 14.11 in. during 1980-81 and 18.30 in. during 1989-90 resulted in water-level declines during those times, but no longterm decline is apparent in Bithlo 1. In well C, water levels in zone 5 have declined. Water levels in zones 3 and 4 declined slightly from 1965-70, but since 1970 no decline is apparent from inspection of the graph. The declines in point-water head in zone 1 result from the increase in the density of water in that zone with time, so the measured head in the column decreases. The equivalent freshwater heads for zone 1 follow the same trend as heads in zone 3 , which contains fresh- water and therefore has no change in density with time.

\section{AQUIFER TESTS}

A series of aquifer tests was performed in the Cocoa well field during this study to obtain information about the hydraulic properties of the various aquifer zones. Slug tests were done in each zone of well C. Two aquifer tests were performed using well $\mathrm{C}$ as an observation well; during a third aquifer test, monitor well $\mathrm{R}$ and supply well 22 were used as observation wells.

\section{Slug Tests}

Slug tests were run in zones 1,3 , and 4 of Cocoa $\mathrm{C}$ and transmissivity values for each zone were 

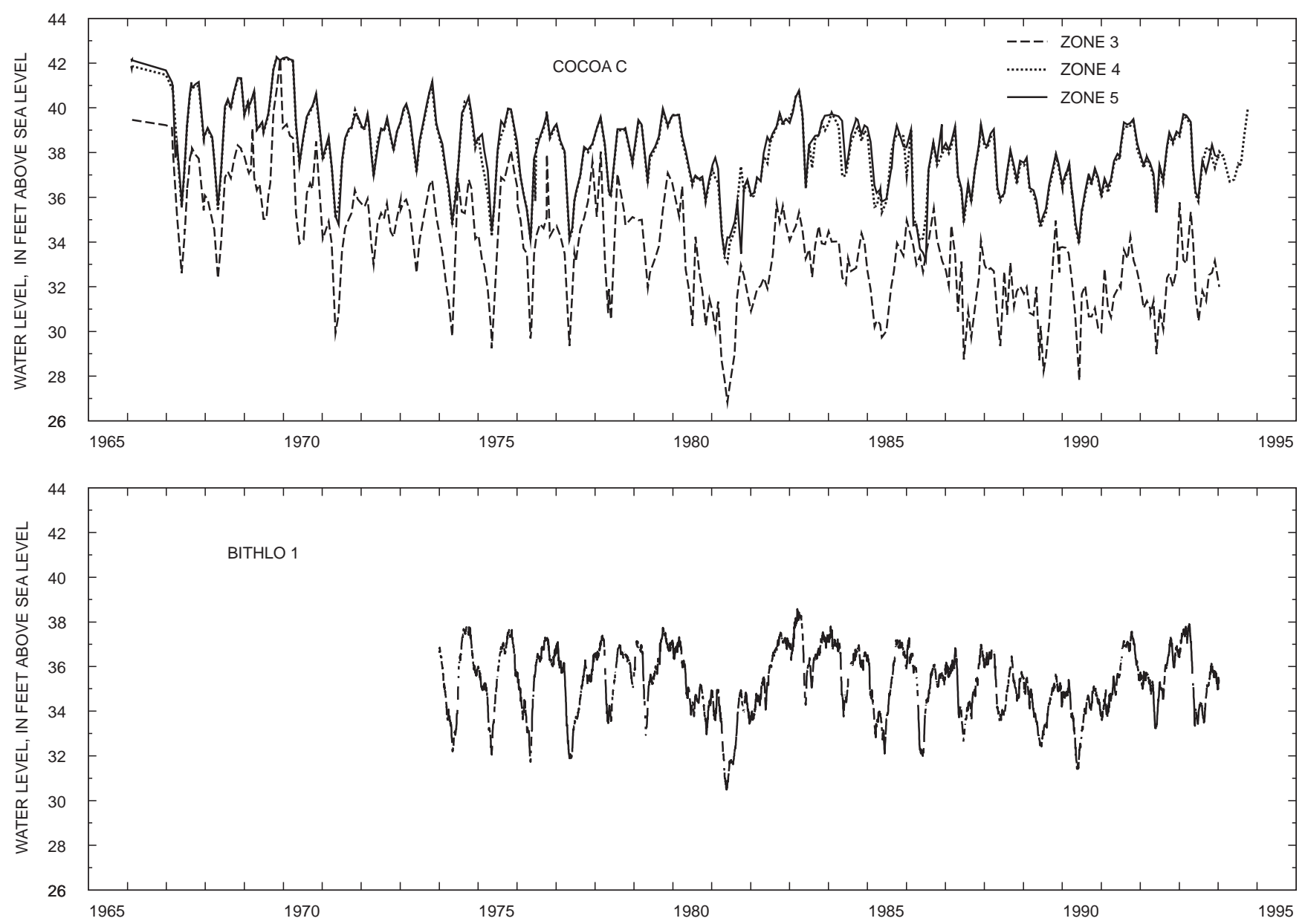

Figure 17. Water levels in zones 3, 4, and 5 of well C, 1966-94, and in well Bithlo 1, 1974-94.

calculated using a method described by Van der Kamp (1976). A pressure transducer was placed $4 \mathrm{ft}$ below the water surface in the monitoring tube, then a bailer was lowered $3 \mathrm{ft}$ into the water to displace the water. After the water-level fluctuations caused by placement of the bailer had dissipated, the bailer was pulled out of the water quickly. This action resulted in a drop in water level of about $3.5 \mathrm{ft}$. After the water level drop, the water in the well oscillated in a manner analogous to an underdamped, simple harmonic oscillator.

The underdamped response is characterized by water levels oscillating around an equilibrium level (Van der Kamp, 1976 and Sepulveda, 1992). For an underdamped response, the water-level value is given by the following equation:

$$
W(t)=W_{o} e^{-\gamma t} \cos (\omega t)
$$

where:

$W(t)$ is the water-level displacement as a function of time, $t$, in feet,

$W_{\mathrm{o}}$ is the initial water-level displacement, in feet, $\omega$ is the angular frequency, in seconds ${ }^{-1}$, $\gamma$ is the damping factor, in seconds ${ }^{-1}$, and $t$ is time, in seconds.

Van der Kamp showed that $\gamma$ and $\omega$ are related to the geometry of the well:

$$
\gamma=\left(\frac{g}{L}\right)^{1 / 2} d
$$

and

$$
\omega=\left(\frac{g}{L}\right)^{1 / 2}\left(1-d^{2}\right)^{1 / 2}
$$


where

$g$ is the acceleration of gravity, in feet per second, squared, and

$L$ is the effective length of the water column in the well, in feet, given by:

$$
L=g /\left(\omega^{2}+\gamma^{2}\right),
$$

$d$ is given by

$$
d=\frac{-r_{c}^{2}\left(\frac{g}{L}\right)^{1 / 2} \log _{e}\left[0.79 r_{f}^{2}\left(\frac{S}{T}\right)\left(\frac{g}{L}\right)^{1 / 2}\right]}{8 T},
$$

where

$T$ is the aquifer transmissivity, in feet squared per day,

$S$ is the aquifer storage coefficient, dimensionless, and

$r_{c}^{2}$ and $r_{f}^{2}$ are the radii of the casing and the open hole, respectively, in feet.

This nonlinear equation relating $T$ and $S$ to $\omega$ and $\gamma$ (eq. 6) can be solved by an iterative process. The variables $\omega$ and $\gamma$ are estimated from the observed waterlevel response during the slug test. Values for $L$ and $d$ were calculated using equations 4 and 5 . Transmissivity values were calculated using a Fortran program written by David Sumner (U.S. Geological Survey, written commun., 1994). The response of heads in zones 1,3 , and 4 of well $\mathrm{C}$ are shown in figure 18 . The method was not applied to zone 5 because water levels in that zone fluctuate in both the outer casing of the well and in the monitoring tube.

The calculated transmissivity values were divided by the thickness of each zone tested $(6 \mathrm{ft})$ to obtain horizontal hydraulic conductivity values, which were about $50 \mathrm{ft} / \mathrm{d}$ for zones 1 and 3 and about $20 \mathrm{ft} / \mathrm{d}$ for zone 4 . These values provide an upper limit for vertical hydraulic conductivity values of the aquifer layers separating the fresh- and saline-water zones. If the Floridan aquifer system were isotropic, the horizontal and vertical hydraulic conductivity values would be equal; however, the aquifer is anisotropic. Based on Hantush (1964, p. 292-293), a value two orders of magnitude less than the horizontal hydraulic conductivity values calculated from the slug tests was used as a first estimate of vertical hydraulic conductivity for the middle semi-confining unit.

Storage-coefficient values used in the calculations were derived from the specific storage calculated from the aquifer test on August 25-27, 1993 (discussed in the next section of this report). The thickness of the pumped zone (zone 5) was about $550 \mathrm{ft}$, so specific storage, $S_{s}$, equals the aquifer storage coefficient divided by the aquifer thickness $\left(2 \times 10^{-4} / 550 \mathrm{ft}=\right.$ $\left.4 \times 10^{-7} \mathrm{ft}^{-1}\right)$. Multiplying this specific storage value by the thickness $(6 \mathrm{ft})$ of the each of the tested zones (zones 1, 3, and 4) results in a storage coefficient of $2 \times 10^{-6}$. The calculated values of horizontal hydraulic conductivity were relatively insensitive to changes in storage coefficient of one order of magnitude.

\section{Aquifer Test 1}

The first aquifer test of this investigation was performed on August 25-27, 1993. Well 14 was pumped at a rate of $1,500 \mathrm{gal} / \mathrm{min}$ for 46 hours. Pressure transducers were used to measure water levels in the zones of Cocoa C and in Cocoa B. A schematic of the pumped- and observation-well completion data is shown in figure 19 and well information is listed in table 2.

Background water levels (August 19-25) and water levels during aquifer test 1 are shown in figure 20. Well 14 was shut off 48 hours prior to the start of the test and allowed to recover. The configuration of pumping wells and pumping rates for the other wells in the well field was held constant during the test. At about 4:45 p.m. on August 25, 1993, (about 4 hours after the start of the test), water levels in well $\mathrm{C}$, zone 5, and in well B began to rise and then fluctuated with time. At about 9 a.m. on August 26 (about 21 hours after the start of the test), water levels in both well $\mathrm{B}$ and in zone 5 of well $\mathrm{C}$ began to fall again. The cause of the water level rise on August 25 is not known, but based on analysis of regional hydrographs and water levels from subsequent aquifer tests, some of the fluctuations of water levels during later hours of the test could be caused by barometric-pressure fluctuations.

The aquifer-test data were analyzed by plotting drawdown and recovery curves. Transmissivity $(T)$ and storage coefficient $(S)$ values for the upper zone of the aquifer (zone 5) were calculated using the recovery data for well B and zone 5 of well C. There was no response in the other zones of well $\mathrm{C}$. The recovery curves (fig. 21) were analyzed using the Theis equation and matching the data to the type curve from Lohman (1972, plate 4). The data curve for zone 5 of well $\mathrm{C}$ is flat and difficult to match. Using the data from well $\mathrm{B}$, the calculated transmissivity was $104,000 \mathrm{ft}^{2} / \mathrm{d}$ and the storage coefficient was $2 \times 10^{-4}$. 

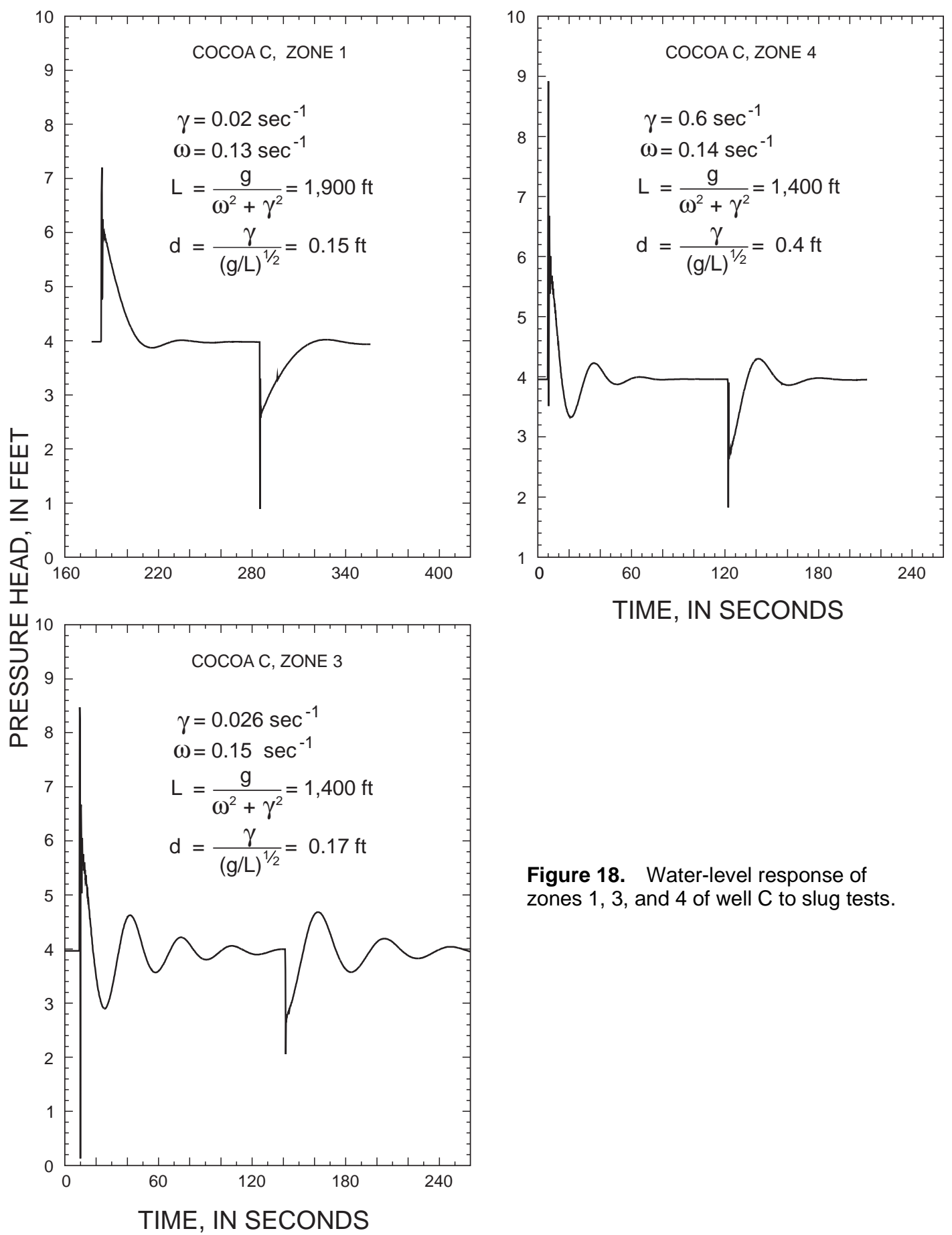

Figure 18. Water-level response of zones 1,3 , and 4 of well $C$ to slug tests.

The horizontal hydraulic conductivity value calculated from this transmissivity value is $200 \mathrm{ft} / \mathrm{d}$, assuming an aquifer thickness of $500 \mathrm{ft}$. These results compare reasonably well with values from an aquifer test performed in 1963 by Lichtler and others (1968, table 14). Transmissivity from that test was $74,000 \mathrm{ft}^{2} / \mathrm{d}$ and the storage coefficient was $3 \times 10^{-4}$.

\section{Aquifer Test 2}

A second aquifer test was performed on November 15-17, 1993, using supply well 21 as the pumped well and supply well 22 and monitor well $\mathrm{R}$ as observation wells. Well $\mathrm{R}$ is about $50 \mathrm{ft}$ from well 21 and is open from 1,098-1,205 ft. Well 21 and well 22 are cased to about $290 \mathrm{ft}$ and completed to a depth of 


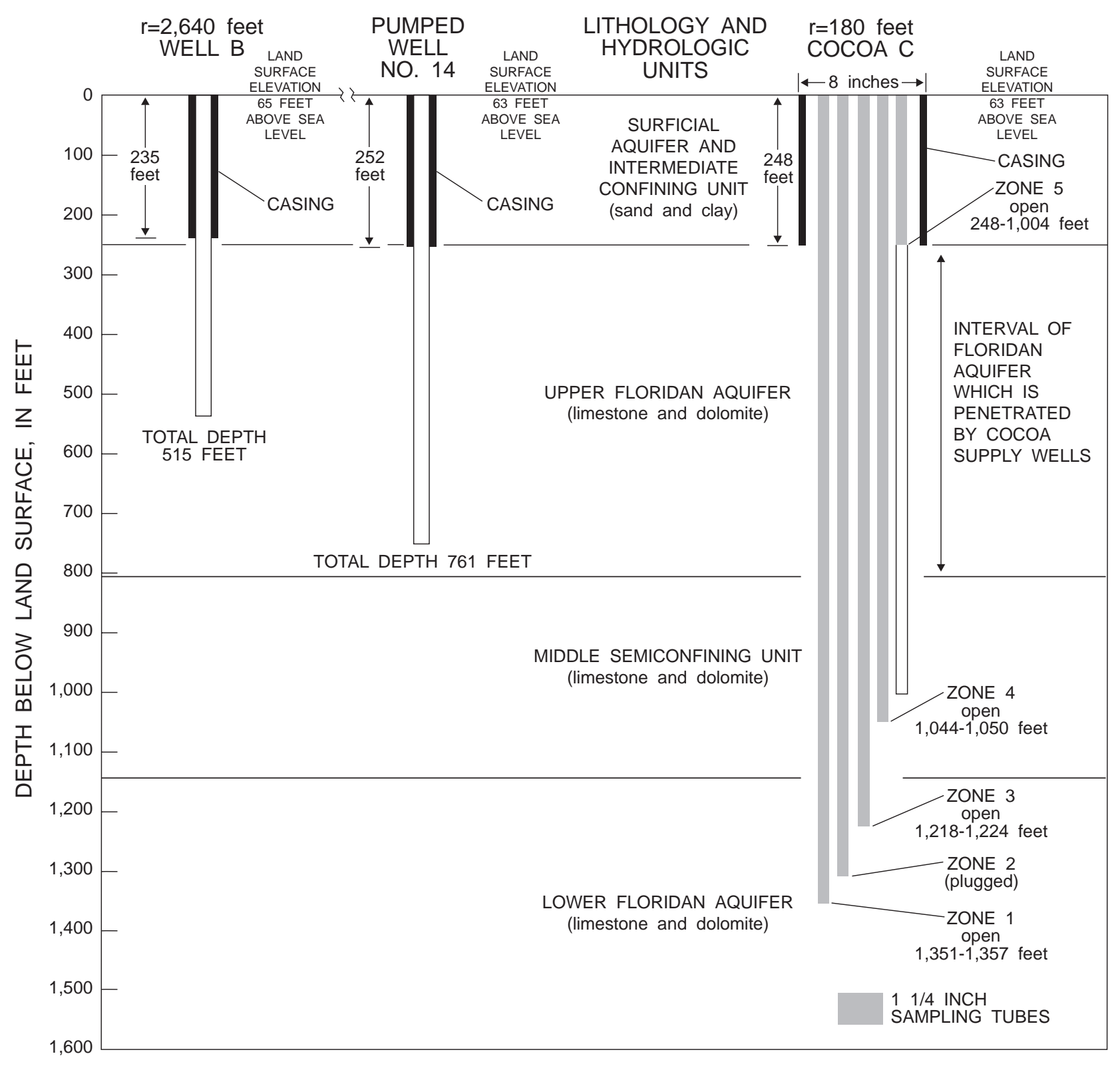

Figure 19. Geohydrologic section showing well-completion data near well C.

Table 2. Well information for August 25-27, 1993, aquifer test

[Locations are shown in figure 1. ft, feet; --, not applicable]

\begin{tabular}{lccccc}
\hline \multicolumn{1}{c}{ Well } & $\begin{array}{c}\text { Site identification } \\
\text { number }\end{array}$ & $\begin{array}{c}\text { Total depth } \\
\mathbf{( f t )}\end{array}$ & $\begin{array}{c}\text { Depth cased or } \\
\text { open interval } \\
(\mathbf{f t})\end{array}$ & $\begin{array}{c}\text { Direction from } \\
\text { pumped well }\end{array}$ & $\begin{array}{c}\text { Distance from } \\
\text { pumped well } \\
\text { (ft) }\end{array}$ \\
\hline & & & & & -- \\
Cocoa 14 (pumped well) & 282531081082201 & 761 & 252 & -- & 2,640 \\
Cocoa B & 282532081075601 & 515 & 235 & East & 180 \\
Cocoa C, zone 1 & 282533081082202 & -- & $1,351-1,357$ & North & 180 \\
Cocoa C, zone 3 & 282533081082204 & -- & $1,218-1,224$ & North & 180 \\
Cocoa C, zone 4 & 282533081082205 & -- & $1,044-1,050$ & North & 180 \\
Cocoa C, zone 5 & 282533081082206 & -- & $248-1,004$ & North & \\
\hline
\end{tabular}



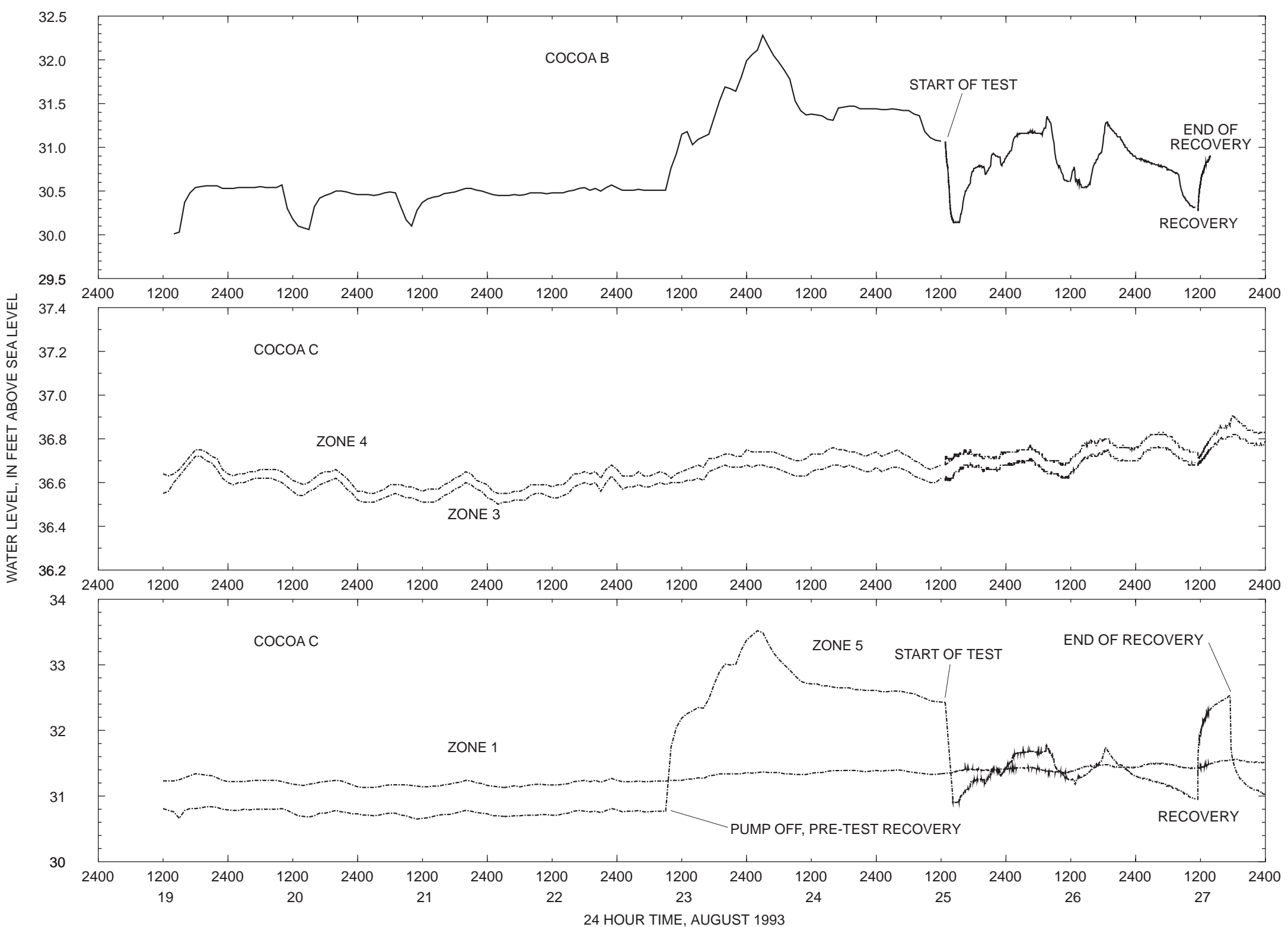

Figure 20. Water levels in wells B and C, August 19-27, 1993. 


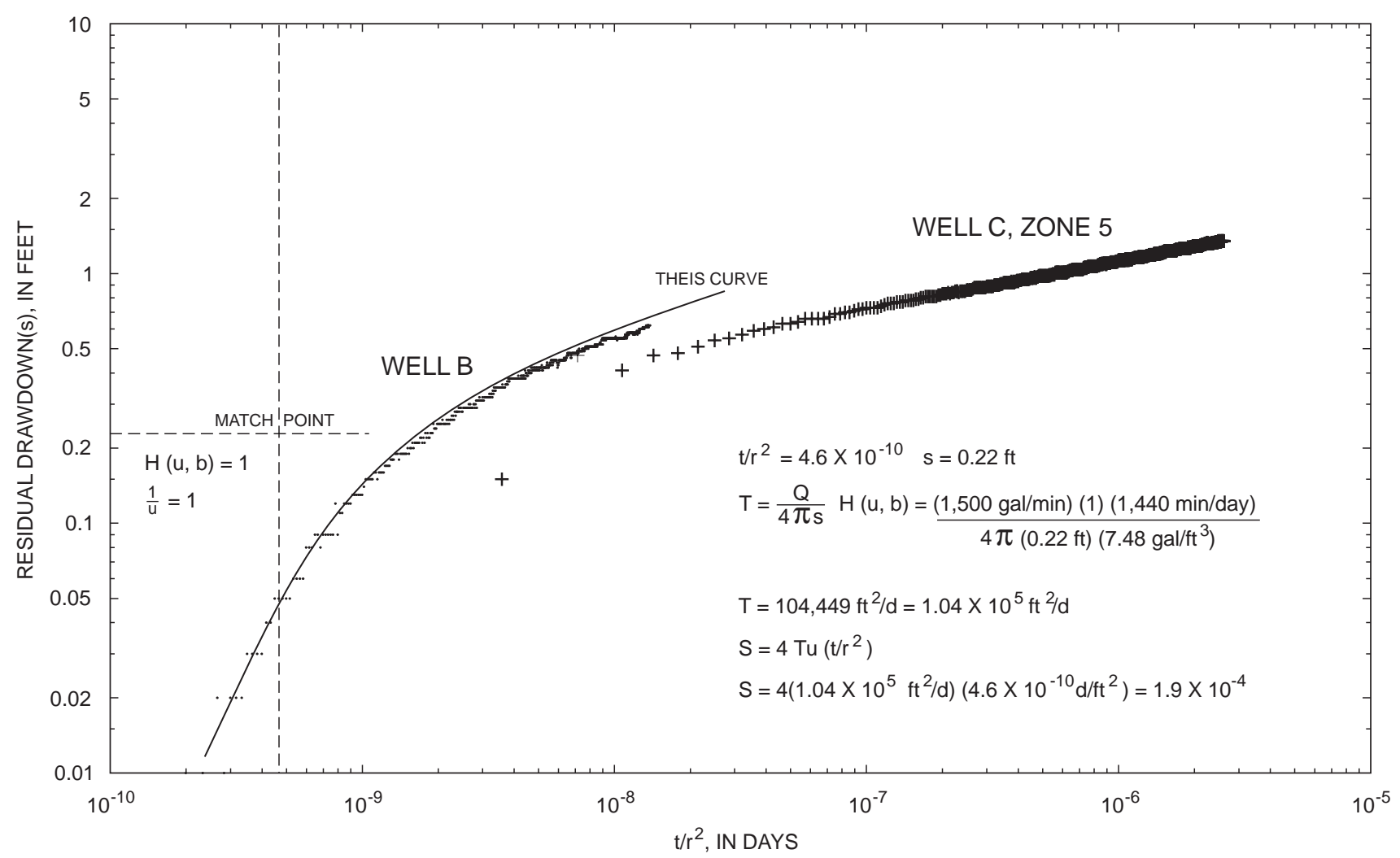

Figure 21. Relation of residual drawdown(s) and ratios of time divided by distance squared $\left(t / r^{2}\right)$ for well B and zone 5 of well C, August 27, 1993.

about $600 \mathrm{ft}$ (fig. 22). Well 22 is about 2,100 ft from well 21, the pumped well. Geophysical logs (fig. 5) for well R from May 1991, before the final casing was installed, indicate that the middle semi-confining unit extends from about 800 to about $1,150 \mathrm{ft}$ below land surface. The temperature and flow logs also indicate that there are small flow zones within the middle semiconfining unit. Prior to the test, water levels in well $\mathrm{R}$ were continuously recorded for 2 weeks. Effects of barometric-pressure fluctuations were seen in these water levels. Part of the record is shown in figure 13.

Well 21 was turned off on November 13, 1993, and allowed to recover for 48 hours. A pressure transducer was installed in well 22 to provide continuous water-level data in the pumped zone. On November 15 , well 21 was pumped at 2,600 gal/min. Pumping continued at that rate for 45 hours. Water levels during the test in wells 22 and $\mathrm{R}$ are shown in figure 23 . There was no apparent water-level response in well $\mathrm{R}$ to pumping from well 21 . The small water-level fluctuations in well $\mathrm{R}$ probably were caused by changes in barometric pressure, as shown in figure 14 .

\section{Aquifer Test 3}

A third aquifer test was performed on February 9, 1994, to determine whether additional pumping stress would cause a measurable response in zone 1 of well C. During the test, pressure transducers were used to measure water levels in the zones of well $C$ while supply wells 14 through 22 were pumped. It was not possible to begin pumping all wells simultaneously; however, each well was turned on about $5 \mathrm{~min}$ after the previous well, beginning with well 14 , nearest well C. The combined pumping rate for wells 14 through 22 was about $18,400 \mathrm{gal} / \mathrm{min}$ or $26.5 \mathrm{Mgal} / \mathrm{d}$. Pumping continued at that rate for 28 hours. Pumping rates for each well during the test are listed in table 3 . The decrease in pumping rates for many of the wells that occurs when all wells are pumping probably is caused by back-pressure in the distribution lines.

The water-level response in zones 1 and 5 of well $\mathrm{C}$ during the aquifer test is shown in figure 24 . The water levels in zone 5 show the effects of pumping but no response was observed in zone 1 . No response was detected in zone 1 during the first 2.5 hours of the test. After that time, if a response 

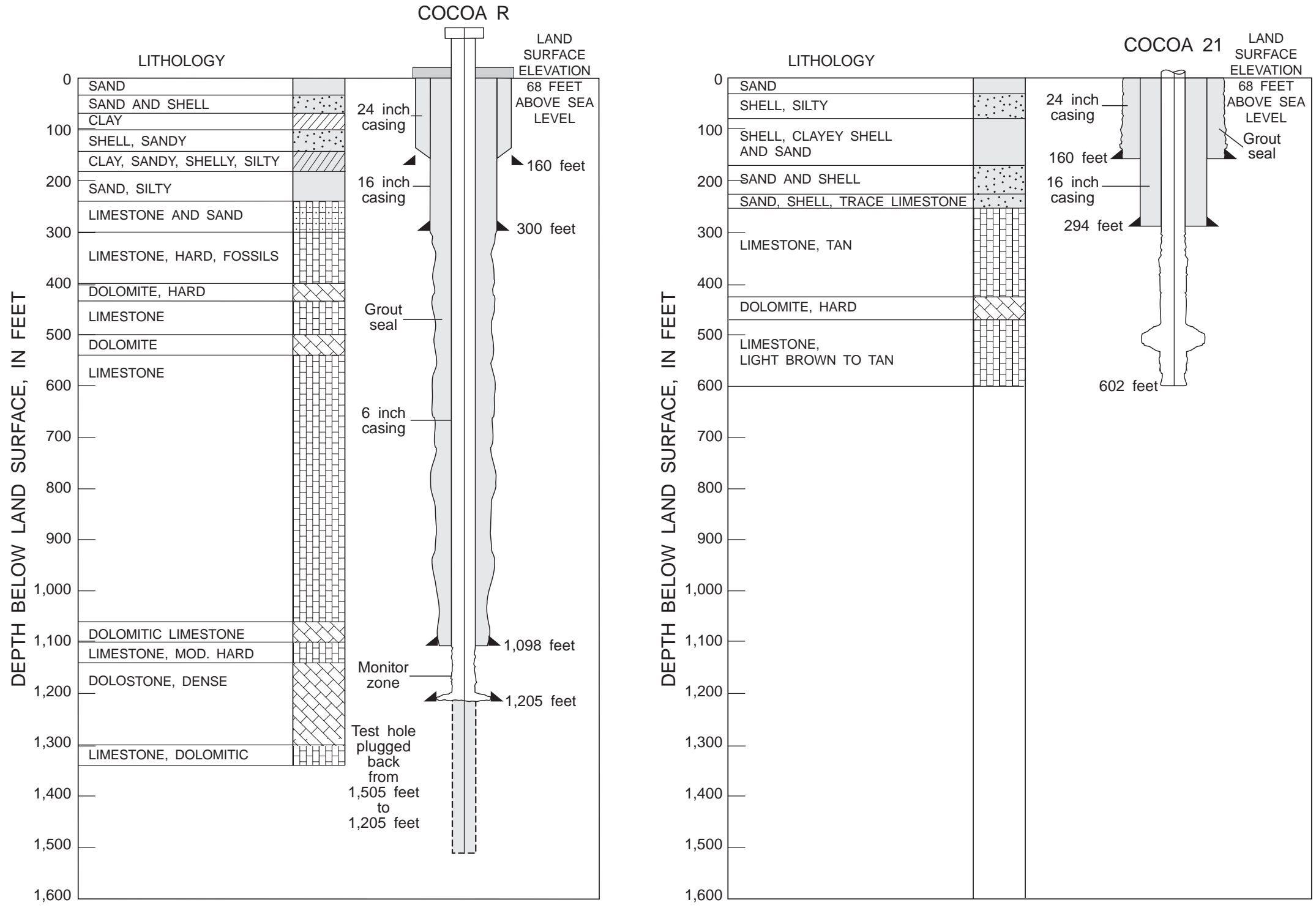

Figure 22. Geohydrologic section showing well-completion data for well R and supply well 21 . 

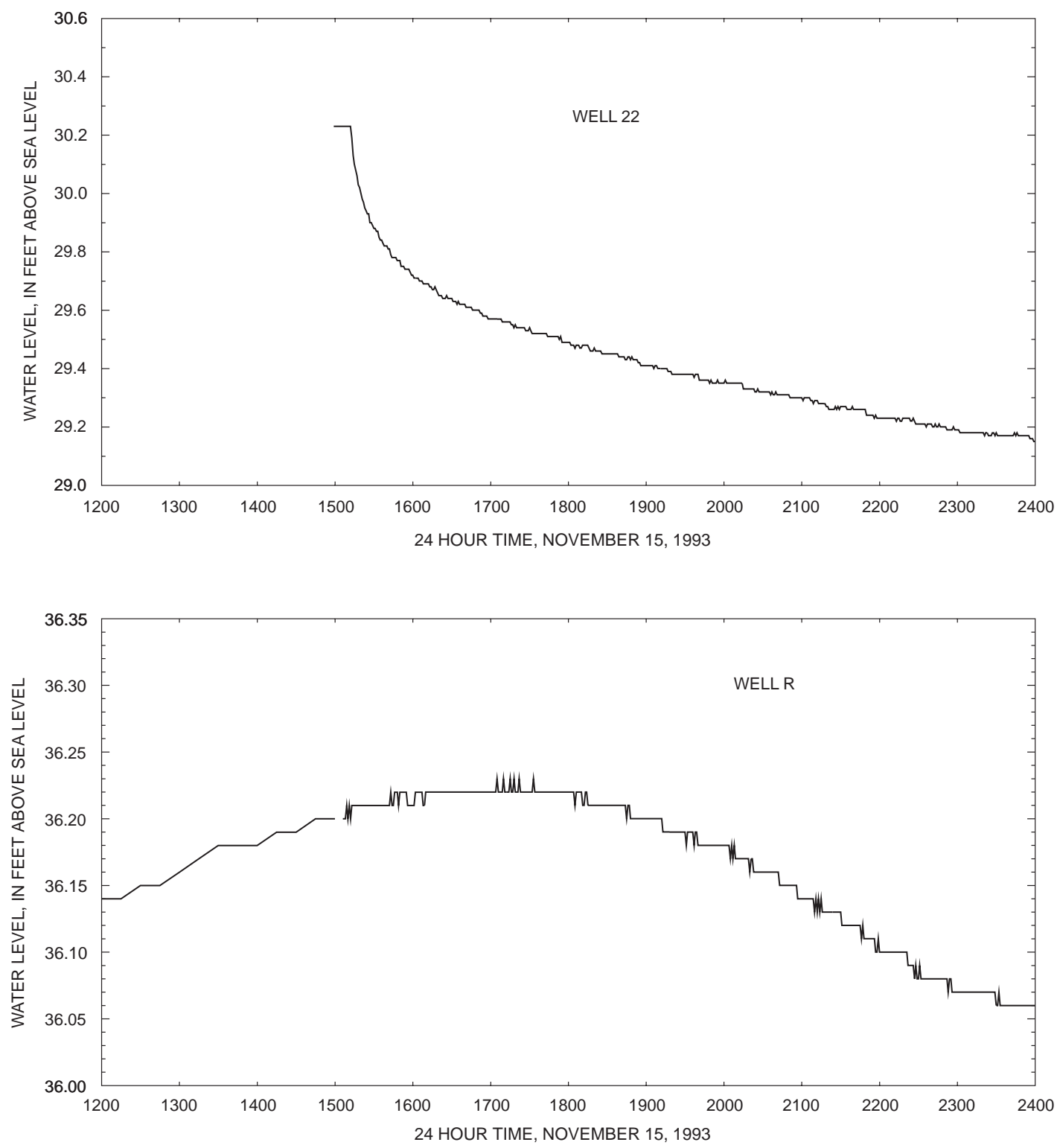

Figure 23. Water levels in well R and supply well 22, November 15, 1993.

Table 3. Pumping rates for February 9, 1994, aquifer test [All times are a.m.; (e), estimated]

\begin{tabular}{cccc||rrrr}
\hline Well no. & Time & $\begin{array}{c}\text { Rate } \\
\text { (gal/min) }\end{array}$ & $\begin{array}{c}\text { Other wells } \\
\text { pumping }\end{array}$ & Well no. & Time & $\begin{array}{c}\text { Rate } \\
\text { (gal/min) }\end{array}$ & $\begin{array}{c}\text { Other wells } \\
\text { pumping }\end{array}$ \\
\hline & & & & & & & \\
14 & $08: 24$ & 1,600 & none & 14 & $09: 33$ & 1,100 & $14-22$ \\
15 & $08: 31$ & 2,250 & 14 & 15 & $09: 28$ & 1,900 & $14-22$ \\
16 & $08: 35$ & 2,200 & $14-15$ & 16 & $09: 25$ & 1,850 & $14-22$ \\
17 & $08: 40$ & 2,450 & $14-16$ & 17 & $09: 20$ & 2,050 & $14-22$ \\
18 & $08: 44$ & 2,450 & $14-17$ & 18 & $09: 17$ & 2,300 & $14-22$ \\
19 & $08: 47$ & 2,100 & $14-18$ & 19 & $09: 12$ & 1,650 & $14-22$ \\
20 & $08: 57$ & $(\mathrm{e}) 2,500$ & $14-19$ & 20 & $09: 10$ & $(\mathrm{e}) 2,500$ & $14-22$ \\
21 & $09: 00$ & 2,663 & $14-20$ & 21 & $09: 07$ & 2,585 & $14-22$ \\
22 & $09: 03$ & 2,550 & $14-21$ & 22 & $09: 04$ & 2,500 & $14-22$ \\
\hline
\end{tabular}




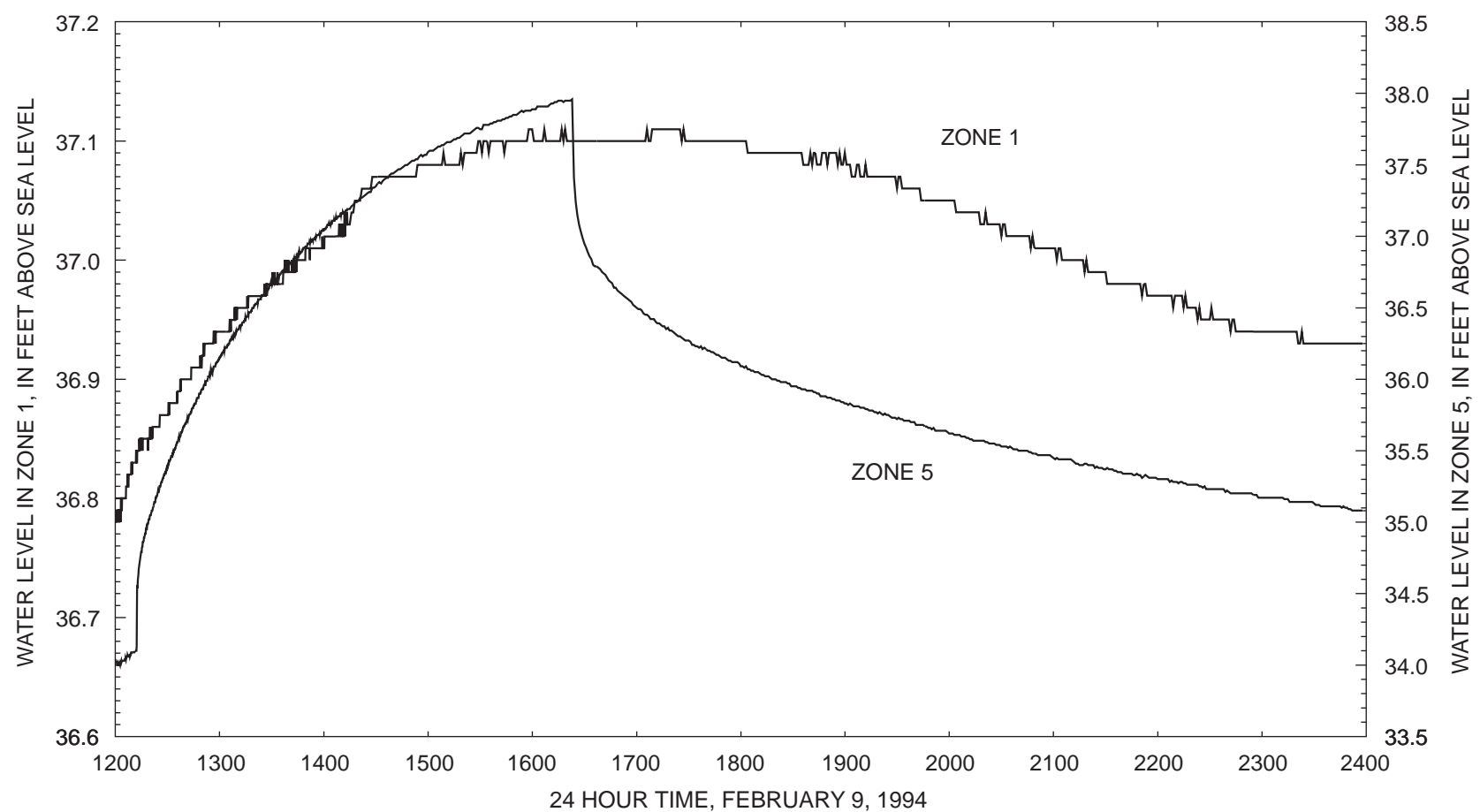

Figure 24. Water levels in zones 1 and 5 of well C, February 9, 1994 (note scale change between plots).

occurred, it was obscured by the barometric or tidal effects on the water level. The effects of pumping apparently are not transmitted vertically through the aquifer from zone 5 to zones 4,3 . or 1 because of the high transmissivity of the Upper Floridan aquifer. Therefore, it is was not possible to calculate the vertical hydraulic diffusivity of the strata between the zones.

\section{FACTORS AFFECTING VERTICAL MOVEMENT OF SALINE WATER}

Saline water, if present in an aquifer, may or may not move vertically through the aquifer. Factors that determine whether or not the saline water will move vertically include the vertical hydraulic conductivity of the aquifer and the vertical hydraulic gradient in the aquifer. If the vertical gradient is downward, saline water cannot move upward. If the vertical hydraulic conductivity is very low, upward movement can occur if the gradient is upward, but the rate of movement will be slow. Porosity also plays a part in that the rate of movement is inversely related to porosity of the aquifer.

\section{Vertical Hydraulic Conductivity}

If saline water is moving vertically upward in the vicinity of Cocoa $\mathrm{C}$, then water would be moving through the middle semi-confining unit (represented by zone 4) to zone 5 (fig. 19). Results of the slug tests for zones 1 and 3 of well $C$ provide estimates of the horizontal hydraulic conductivity in the Lower Floridan aquifer and zone 4 provides an estimate for the middle semi-confining unit. The hydraulic conductivity values calculated from the slug tests probably represent horizontal hydraulic conductivities for the 6-ft thickness of aquifer tested. For zones 1 and 3, the hydraulic conductivity calculated from the slug tests was about $50 \mathrm{ft} / \mathrm{d}$. For zone 4 , the value was about $20 \mathrm{ft} / \mathrm{d}$. The hydraulic conductivity for zone $5 \mathrm{calcu}-$ lated from aquifer test 1 was about $200 \mathrm{ft} / \mathrm{d}$. Therefore, the hydraulic conductivity of zone 5 is greater than that of the underlying zones by at least a factor of four.

A first estimate of vertical hydraulic conductivity of the middle semi-confining unit is about $0.2 \mathrm{ft} / \mathrm{d}$, based on the horizontal hydraulic conductivity value for zone 4 of about $20 \mathrm{ft} / \mathrm{d}$ calculated from the slug tests. A more conservative estimate for the vertical hydraulic conductivity of the middle semi-confining unit is $0.5 \mathrm{ft} / \mathrm{d}$, based on the horizontal hydraulic conductivity values for the Lower Floridan aquifer 
(zones 1 and 3 ) of about $50 \mathrm{ft} / \mathrm{d}$. The thickness of the middle semi-confining unit is about equal to the thickness of sediments between the bottom of well 14 and the top of zone 4 , or about $280 \mathrm{ft}$.

The hydraulic diffusivity (and the vertical hydraulic conductivity for a given value of specific storage) for an aquitard can be calculated based on the ratio of drawdown in the aquitard to drawdown in the aquifer using a method described by Neuman and Witherspoon (1972). Because no drawdown attributable to pumping was observed in zone 1 during the aquifer tests, the method could not be used directly. Instead, the method was used to calculate the drawdown expected to occur in zone 4 when zone 5 was pumped, if the vertical hydraulic conductivity of the intervening aquitard were equal to a particular estimated value. Expected drawdowns were calculated for zone 4 using the water-level data in well $\mathrm{C}$ during aquifer test 1 (August 1993) at times of 0.1 day (144 min.) and 1 day (1440 min.) and a range of possible vertical hydraulic conductivity and specific storage values. A value of $t_{D}$ (dimensionless time) for the aquifer was calculated using an equation from Neuman and Witherspoon (1972, eq. 8):

$$
t_{D}=(T t) \div\left(S r^{2}\right)
$$

where

$T$ is aquifer transmissivity, 100,000 feet squared per day,

$t$ is arbitrary time since the start of pumping, in days,

$S$ is storage coefficient of the aquifer, $2 \times 10^{-4}$, and

$r$ is distance from the observation well to the pumped well, in feet.

A value of dimensionless time for the aquitard $\left(t_{D}^{\prime}\right)$ was calculated using equation 6 from Neuman and Witherspoon (1972) and the estimated values of $K^{\prime}$ and $S_{s}{ }^{\prime}$ :

$$
t_{D}^{\prime}=\left(K^{\prime} t\right) \div\left(S_{s}{ }^{\prime} z^{2}\right)
$$

where

$K^{\prime}$ is the vertical hydraulic conductivity of the aquitard, in feet per day,

$t$ is arbitrary time since the start of pumping, in days,

$S_{S}{ }^{\prime}$ is the specific storage of the aquitard, in feet ${ }^{-1}$, $z$ is the vertical distance between the top of the aquitard and the point in the aquitard at which head is being measured, about 280 feet.

Also,

$s$ is the drawdown in the aquifer, in feet, and $s^{\prime}$ is the drawdown in the aquitard, in feet.

Using the calculated values of $t_{D}$ and $t_{D}^{\prime}$ and the type curves (Neuman and Witherspoon, 1972, fig.3), a value of the ratio of drawdowns $\left(s^{\prime} / s\right)$ can be determined. From the aquifer test data, the value of $s$ at time $t$ is known and thus $s^{\prime}$ (expected drawdown in the aquitard) can be calculated.

For a vertical hydraulic conductivity of $0.5 \mathrm{ft} / \mathrm{d}$ and specific storage of $7 \times 10^{-7} \mathrm{ft}^{-1}$, the expected drawdown in zone 4 at time 0.1 day is $0.67 \mathrm{ft}$. There was no drawdown observed in zone 4 at that time, indicating that the vertical hydraulic conductivity probably is less than $0.5 \mathrm{ft} / \mathrm{d}$ (or possibly that the specific storage is greater than the assumed value). For time equal 1 day, the expected drawdown in zone 4 was $0.92 \mathrm{ft}$. Again, because there was no drawdown observed in zone 4, the vertical hydraulic conductivity of the aquitard probably is less then $0.5 \mathrm{ft} / \mathrm{d}$.

If the vertical hydraulic conductivity is estimated to be $0.05 \mathrm{ft} / \mathrm{d}$ and the specific storage $7 \times 10^{-7} \mathrm{ft}^{-1}$, the expected drawdown in zone 4 at time 0.1 day was $0.02 \mathrm{ft}$. and at time equal 1 day, the expected drawdown was $0.52 \mathrm{ft}$. No drawdown was observed at 1 day. The expected drawdown of $0.02 \mathrm{ft}$ at time equal 0.1 day is approaching the limit that can be measured with pressure transducers. From these calculations, the upper limit for vertical hydraulic conductivity of the middle semi-confining unit probably is less than $0.05 \mathrm{ft} / \mathrm{d}$ assuming a specific storage of $7 \times 10^{-7} \mathrm{ft}^{-1}$.

\section{Vertical Hydraulic Gradient}

Another factor affecting the upward movement of saline water is the direction and magnitude of the vertical hydraulic gradient in the aquifer. In the Cocoa well field, calculation of the vertical hydraulic gradient is complicated by the fact that the density of the ground water is different from zone to zone. Some of the problems of evaluating flow in aquifers with water of different density have been discussed by Reilly (1993).

The vertical hydraulic gradient in water with variable density can be determined by compar- 
ing environmental-water heads, as described by Lusczynski (1961). The environmental-water head is the head that would be measured in a column of water with a density distribution identical to that in the aquifer. The difference between the environmental-water heads in zone 3 and zone 1 can be calculated using Lusczynski's equation 9 (1961):

$$
h=\frac{\rho_{1} H_{1 p}-\rho_{2} H_{2 p}+Z_{2}\left(\rho_{2}-\rho_{a}\right)+Z_{d}\left(\rho_{a}-\rho_{1}\right)}{\rho_{1}}
$$

where:

$h$ is the difference between the environmentalwater heads at point 1 ,

(in zone 3 ) and point 2 (in zone 1), in feet above sea level,

$Z_{2}$ is the altitude at point $2(-1,288 \mathrm{ft})$,

$Z_{d}$ is the altitude at the contact between freshwater and diffused water, assumed to be at point $1(-1,161 \mathrm{ft})$,

$H_{l p}$ is the point-water (measured) head at point 1 , in feet above sea level,

$\mathrm{H}_{2 p}$ is the point-water (measured) head at point 2, in feet above sea level,

$\rho_{l}$ is the density of water at point $1(0.9993 \mathrm{~g} / \mathrm{mL}$, a constant),

$\rho_{2}$ is the density of the water at point 2 $(1.0028 \mathrm{~g} / \mathrm{mL}$ in 1994$)$, and

$\rho_{a}$ is the estimated mean density of the water in the zone of mixed water, in $\mathrm{g} / \mathrm{mL}$ (actual density is unknown).

A schematic geohydrologic section illustrating the variables in equation 9 is shown in figure 25 .

Using equation 9, the difference between environmental-water heads was calculated for the water levels measured in zones 1 and 3 from 1966-94 (fig. 26). During most of the period of record, the head in zone 3 is about $0.5-1.0 \mathrm{ft}$ higher than the calculated head at the interface, indicating a downward gradient. However, a few times the gradient was upward, particularly in 1986. In the calculations, the density of water in zone 1 at the time of the measurement was calculated from the measured chloride concentration in the water at the time. Although the chloride concentration throughout the freshwater part of the aquifer is not uniform (about $80 \mathrm{mg} / \mathrm{L}$ in zone 3 and $140 \mathrm{mg} / \mathrm{L}$ in zone 5), the calculated values of density for the two zones were 0.9993 and $0.9994 \mathrm{~g} / \mathrm{mL}$, respectively, and so density in the freshwater part of the aquifer was assumed to be constant.

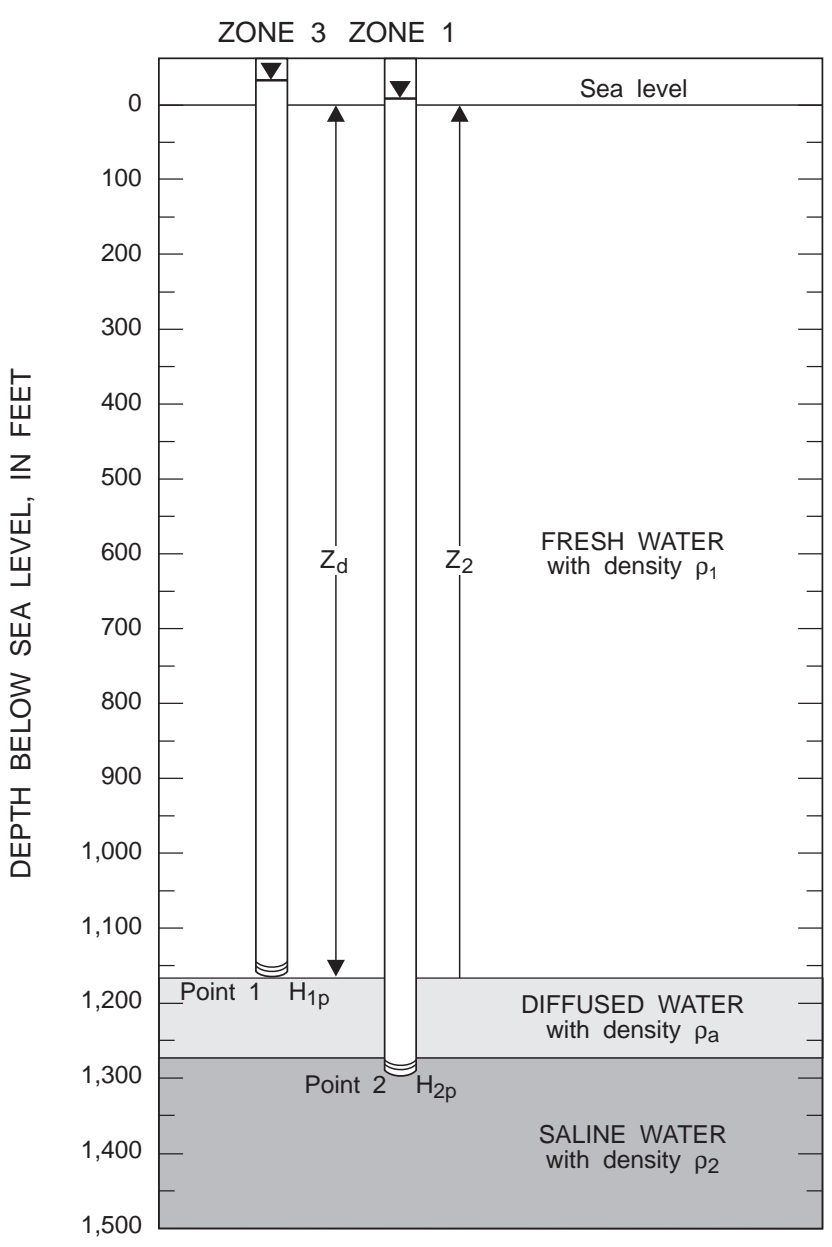

Figure 25. Geohydrologic section identifying variables for calculating hydrostatic head in ground water with variable density.

\section{POTENTIAL FOR UPWARD MOVEMENT OF SALINE WATER}

The estimates of vertical hydraulic conductivity and vertical hydraulic gradient calculated during this study were used with the existing water-quality data to draw some conclusions about the potential for upward movement of saline water in the Cocoa well field. The movement of saline water in the area is a complex problem. A combination of lateral and vertical movement of saline water may be occurring in both the Upper and Lower Floridan aquifers.

Based on the results of the aquifer tests run during this study, the chloride concentration increase in water from zone 1 of well $\mathrm{C}$ probably is not directly related solely to pumping from nearby wells 14 and 15 . Pumping at a rate of about 50-60 Mgal/d from the Lower Floridan in Orlando since the 1960's may 


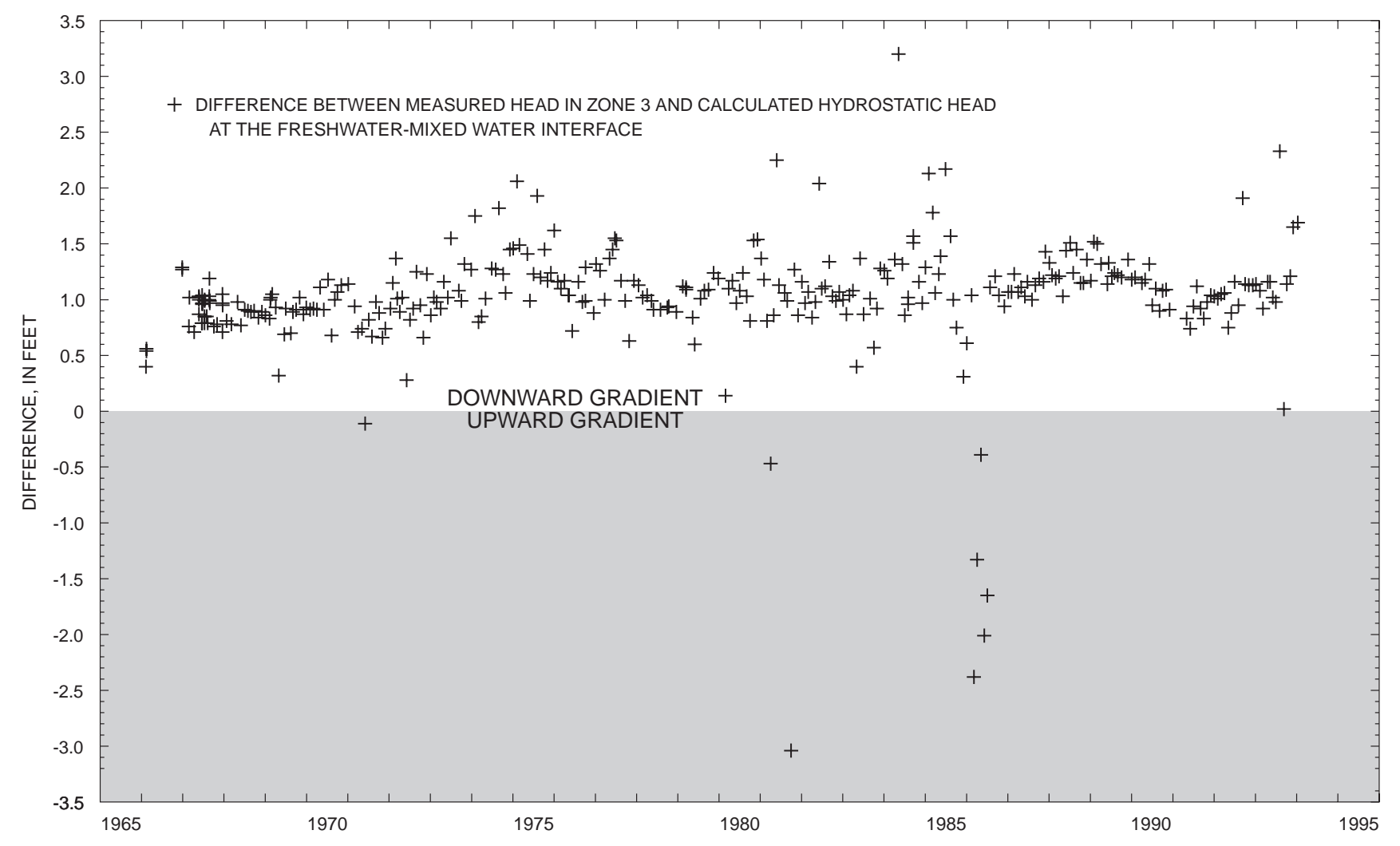

Figure 26. Difference between head in zone 3 of well $\mathrm{C}$ and calculated hydrostatic head at the freshwater-mixed water interface, 1965-94.

have contributed to a head decrease that could have induced either upconing or lateral movement of saline water in zone 1. A monitor well in the Lower Floridan aquifer in Orlando, Fla., (the Lake Ivanhoe well, fig. 7) was completed in 1989. Water-level declines have not been observed in the well during the relatively short period of record (1989-94, fig. 27), but it is possible that a cone of depression in the Lower Floridan aquifer from pumping in the Orlando area extends to the Cocoa well field. If this is the case, water from the east with a higher chloride concentration could be drawn to the Cocoa well field.

Analysis of flow directions and understanding of areal water-quality variations in the Lower Floridan aquifer in central Florida are difficult because of the paucity of deep monitor wells. Regionally, water flows from west to east. The water level in the Lake Ivanhoe well in Orlando was $47.48 \mathrm{ft}$ above sea level on February 24,1994 . The water level in well $\mathrm{R}$ (about $17 \mathrm{mi}$ east-southeast of Lake Ivanhoe) was $37.29 \mathrm{ft}$ above sea level on February 16, 1994. However, in the Cocoa well-field area, there is some evidence of local flow from east to west. At well C, about 2 mi northeast of well R (fig. 1), a water level of $39.63 \mathrm{ft}$ above sea level was estimated for the depth interval tapped by well R, using the water levels measured in zones 3 and 4 on February 16, 1994. This is about $2.3 \mathrm{ft}$ higher than the water level in well $\mathrm{R}$ and indicates the potential for flow of water from northeast to southwest in the Lower Floridan aquifer, which could allow westward movement of saline water in the well-field area.

The interface between freshwater and saline water is shallower in the Cocoa well field than in the Lake Ivanhoe area. On February 24, 1994, the chloride concentration in water from the zone of the Lake Ivanhoe well open from 2,060-2,089 ft below sea level was $80 \mathrm{mg} / \mathrm{L}$. At well R, the chloride concentration increases from about 80 to $1,000 \mathrm{mg} / \mathrm{L}$ between $1,180-1,340 \mathrm{ft}$ below land surface $(1,100-1,270 \mathrm{ft}$ below sea level) (fig. 11). Therefore, the freshwatersaline water interface is at least $800 \mathrm{ft}$ deeper at Lake Ivanhoe than at the Cocoa well field. At well R, a chloride concentration of $2,500 \mathrm{mg} / \mathrm{L}$ was measured in water at a depth of 1,390 ft below sea level, but at well $\mathrm{C}$, water with a chloride concentration of about $2,600 \mathrm{mg} / \mathrm{L}$ occurs at a shallower depth of $1,290 \mathrm{ft}$ below sea level. 


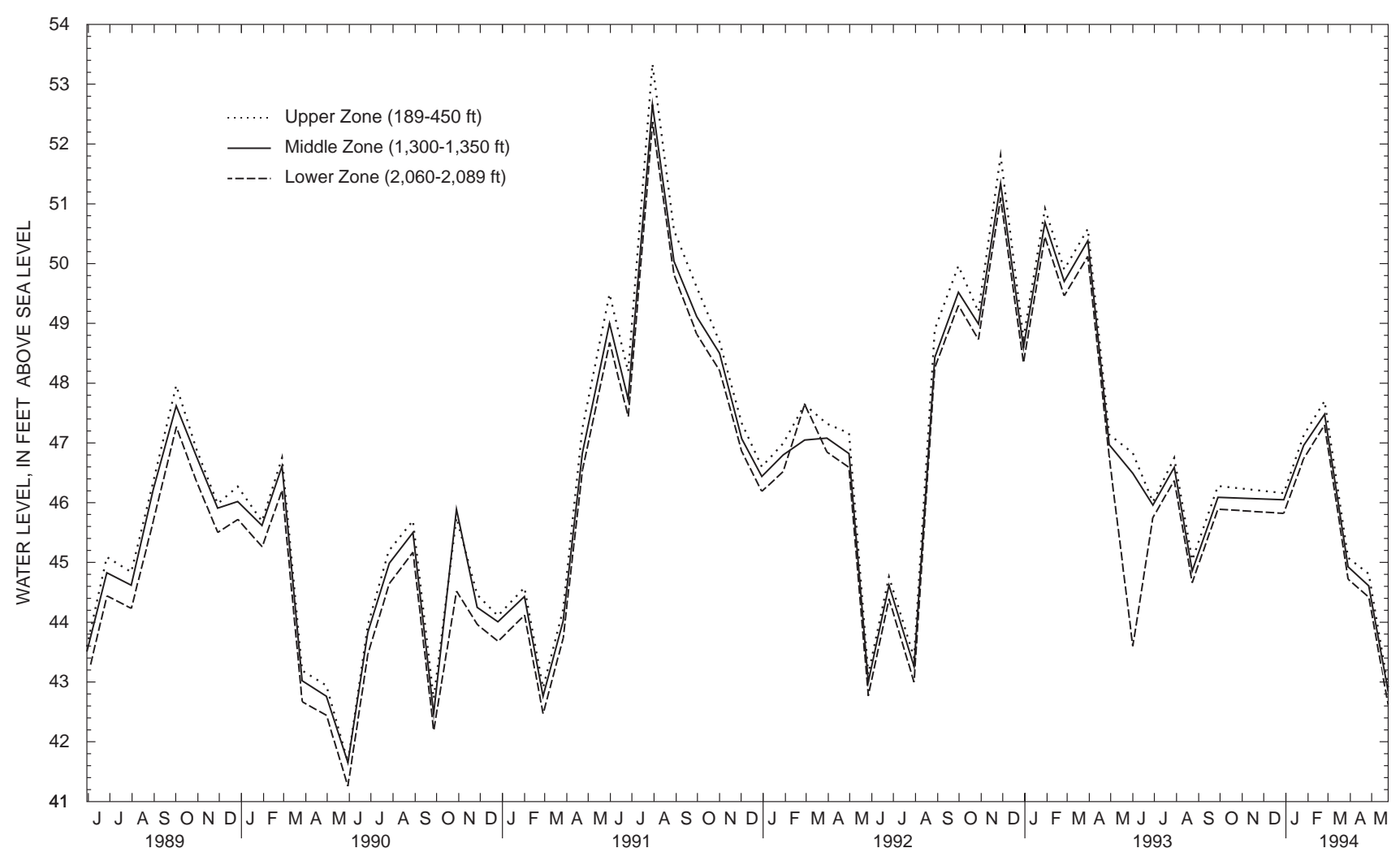

Figure 27. Water levels in the Lake Ivanhoe well, Orlando, Fla., 1989-94.

The long-term fluctuations in chloride concentrations in water from zone 1 (fig. 2) also were examined with respect to pumping from wells 14 and 15, which are closest to Cocoa $C$. If vertical fractures were present in the immediate area of the wells, chloride concentrations might be expected to fluctuate with the pumping rates in those wells. A graph showing chloride concentrations in water from zone 1 of well C with time compared to pumping rates in wells 14 and 15 from 1965-94 did not show any consistent relation (fig. 28). The chloride concentration in zone 1 increases with time, but no obvious causal correlation between pumping from wells 14 or 15 and chloride concentration is apparent. Also, if pumping from wells 14 or 15 affected chloride concentration in zone 1 , it would also be expected to affect chloride concentrations in zones 3 and 4 . However, chloride concentrations in water from zones 3 and 4 have remained relatively constant, regardless of pumping rates for wells 14 and 15. Therefore, the graphs (fig. 28) indicate that fluctuations in chloride concentration in water from zone 1 are not directly related to pumping from wells 14 and 15 .
Conversely, the increases in chloride concentration in water from well 15 are not necessarily a result of chloride increases in zone 1. Although chloride concentrations are increasing in well 15 more rapidly than in well 14 (which is farther east), this could be the result of local variations in chloride concentration in the aquifer or variations in the transmissivity and the local flow system. Such variations could result in more freshwater being drawn to well 14 while saltier water is drawn to well 15. For example, when wells 18-22 are pumping they intercept freshwater that would otherwise flow to well 15.

The chloride changes in water from wells in the Cocoa well field are the result of complex processes. Drillstem-chloride data from well S indicate that fresher and saltier water interfinger in the Upper Floridan aquifer. Lateral movement of saline water from east to west in the Upper Floridan aquifer (zone 5) probably affects the supply wells, based on the fact that wells in the eastern part of the well field produce water with a higher chloride concentration than wells in the western part. However, the source of the saline water is uncertain. Geophysical logs of test wells, long-term chloride concentration data from zones 3 

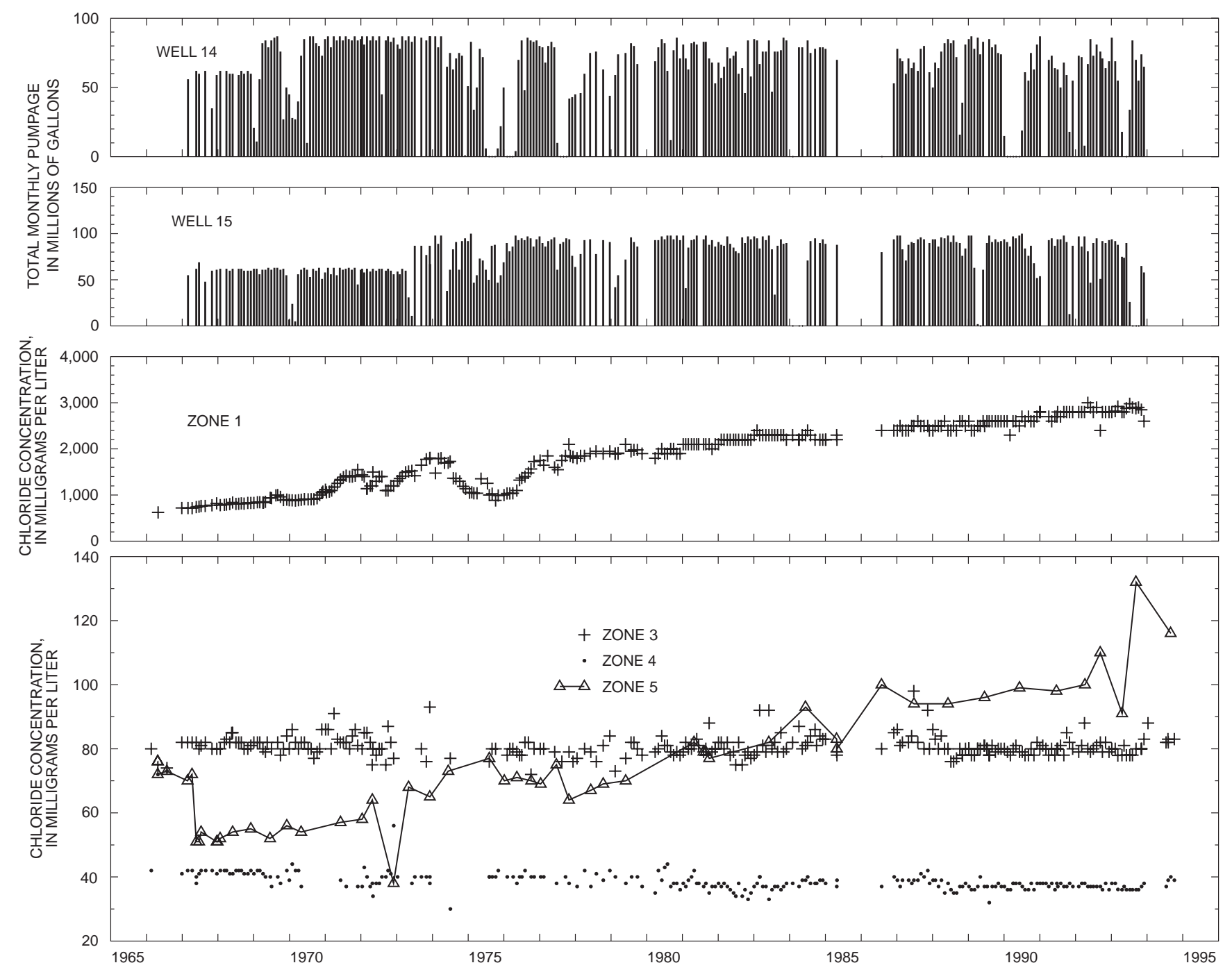

Figure 28. Total monthly pumpage from wells 14 and 15 and chloride concentration in water from zones of well C, 1967-94.

and 4 of well $\mathrm{C}$, and aquifer-test data from this study indicate that the middle semi-confining unit probably is tighter west of well S. However, the middle semiconfining unit may be more permeable in the east (the old well field) or it may be breached by fractures. If saline water is upconing into the Upper Floridan aquifer from the Lower Floridan aquifer in the Cocoa well field, upconing is most likely taking place in the northeast part of the well field, based on the comparison of chloride concentration with well depth (fig. 9). A combination of both lateral and upward movement of saline water may also be occurring in the Lower Floridan aquifer (zone 1).

Additional test wells in the area of supply well 3 and east of supply well 1 could provide useful information about the areal extent of the middle semi- confining zone, the direction of the vertical hydraulic gradient, and the vertical distribution of saline water east of the well field. Data from additional test wells also could be used to help determine if the saline water that has caused increased chloride concentrations in water from wells in the old well field resulted from lateral movement in the Upper Floridan aquifer or vertical movement from the Lower Floridan aquifer.

\section{SUMMARY AND CONCLUSIONS}

The Floridan aquifer system in central Florida is an approximately 2,000-foot thick sequence of Eocene-age limestone and dolomite. Hydraulic conductivity is different in strata of different lithology and is the basis for separating the aquifer system into the 
Upper Floridan aquifer, a middle semi-confining unit, and the Lower Floridan aquifer.

The Floridan aquifer system is the main source of water supply in central Florida. The city of Cocoa withdraws about 26 million gallons per day of water from the Upper Floridan aquifer from a well field in east Orange County. In the Orlando area, about 15 miles to the west, about 60 million gallons per day are withdrawn from the Upper Floridan aquifer and 56 million gallons per day from the Lower Floridan aquifer.

The regional direction of ground-water flow in the Upper Floridan aquifer is generally from west to east in the area of the Cocoa well field. The altitude of the potentiometric surface fluctuates seasonally about 5 feet. The potentiometric surface measured in the well-field area in May 1994 was about 10 feet lower than that measured in May 1961, following a year with record high rainfall (68.74 inches) in 1960. The decline probably is related both to withdrawals of water and to a cumulative rainfall deficit of about 35 inches for 1970-85.

Chloride concentrations began to increase in water from wells in the Cocoa well field soon after the well field was put into service in 1955. Generally, the wells farthest east in the well field produce water with the highest chloride concentrations. For example, in 1994 the chloride concentration in water from well 7A (open to the Upper Floridan aquifer) was about 235 milligrams per liter (mg/L), but farther west in well 16 (also open to the Upper Floridan aquifer) the chloride concentration was about $90 \mathrm{mg} / \mathrm{L}$. The possible sources of water with increased chloride concentration are lateral movement of relict seawater in the Upper Floridan aquifer from the east or upconing of saline water from lower zones of the Lower Floridan aquifer or underlying older rocks. Several wells were drilled to provide information about chloride changes with depth and to monitor changes with time, including a multi-zone well that was drilled in 1965 (well C) and 2 wells drilled in the 1990's (wells R and S).

Chloride concentrations have increased in water from well $\mathrm{C}$ in the zone pumped by the supply wells (zone 5, open from 248-1,004 feet below land surface) and in the deepest zone of the well (zone 1, open from 1,351-1,357 feet below land surface), but not in the intervening zones 3 and 4 . Chloride concentrations in zone 5 increased from about $75 \mathrm{mg} / \mathrm{L}$ in 1966 to about $120 \mathrm{mg} / \mathrm{L}$ in 1994 and in zone 1 from about $600 \mathrm{mg} / \mathrm{L}$ to about $3,000 \mathrm{mg} / \mathrm{L}$. During the same time period, the concentrations have remained at about $40 \mathrm{mg} / \mathrm{L}$ in zone 4 and $80 \mathrm{mg} / \mathrm{L}$ in zone 3 .

Water levels have been recorded in the Cocoa well field from 1966 to 1995 and at Bithlo, about 5 miles north of the well field, from 1974 to 1995. Water levels in the Upper Floridan aquifer in the well-field area have declined through time. Water levels in well Bithlo 1 show no decline. In zones 3 and 4 of well C, water levels declined slightly from 1965-70, but since 1970 no decline is apparent. The equivalent freshwater heads for zone 1 of well $\mathrm{C}$ follow the same trend as water levels in zone 3.

The potential for upward movement of saline water in the Floridan aquifer system depends on the direction of the vertical hydraulic gradient in the aquifer and on the vertical hydraulic conductivity of the middle semi-confining unit. To evaluate the hydraulic properties of the aquifer, a series of aquifer tests was conducted. Slug tests in zones 1, 3, and 4 indicate that the horizontal hydraulic conductivities are about 50 feet per day for zones 1 and 3 and about 20 feet per day for zone 4. During an aquifer test in which supply well 14 was pumped at a rate of 1,500 gallons per minute for 46 hours, no response attributable to pumping was observed in water levels in zones 1,3 , and 4 of well C, 180 feet away. Transmissivity calculated from the test was 104,000 feet squared per day. There was also no response attributable to pumping in well $\mathrm{R}$ when supply well 21 was pumped and no response in zones 1,3 , and 4 of well $\mathrm{C}$ or well $\mathrm{R}$ when wells 14-22 were pumped simultaneously. This indicates that the vertical hydraulic conductivity between zones 4 and 5 is very low.

Horizontal hydraulic conductivity values from the slug tests were used as upper limits for vertical hydraulic conductivity values to calculate expected drawdowns in zone 4 using the ratio method described by Neuman and Witherspoon (1972). Results of the analysis indicate that the upper limit of vertical hydraulic conductivity for the middle semi-confining unit of the Floridan aquifer system in the Cocoa well field is about 0.05 feet per day for a specific storage of $7 \times 10^{-7}$.

The vertical hydraulic gradient is determined by comparing water levels in the various zones, but because of density differences, water levels in zone 1 of well C cannot be directly compared to water levels in the overlying zones containing freshwater. The equilibrium head at the contact between freshwater and saline water was calculated and compared to the 
measured head in zone 3, which contains freshwater. During most of the period of record (1966 to 1994), the head in zone 3 was about 0.5 to 1.0 foot higher than the head at the underlying interface, indicating a downward gradient. However, a few times the gradient was upward, particularly in 1986.

Based on the low vertical hydraulic conductivity values, the generally downward vertical hydraulic gradient, and the constant chloride concentrations in zones 3 and 4 of well $\mathrm{C}$, the chloride increases in zone 1 of well $\mathrm{C}$ probably are not directly related to chloride concentration increases in water from nearby supply wells. The combined long-term effects of pumping from the Lower Floridan aquifer in the Orlando area, along with head reductions in the Upper Floridan aquifer from pumping in the Cocoa well field, might have allowed water with higher chloride concentration to move into zone 1, either from the east or from below. The increased chloride concentrations in the Upper Floridan aquifer in the Cocoa well field probably are not caused by upconing from zone 1 in the center and western parts of the well field. However, the middle semi-confining zone could be more permeable in the eastern part of the well field or could be breached by fractures. Additional test wells could provide more information about the source of the saline water.

\section{SELECTED REFERENCES}

Blandford, T.N., and Birdie, T.R., 1992, Ground-water flow and solute transport modeling study for eastern Orange County, Florida and adjoining regions: St. Johns River Water Management District Special Publication SJ93-SP4, secs. 1-5. (Pages are numbered by section, not consecutively).

CH2M Hill, 1993, Results of drilling and testing, production wells 20, 21, 22 and monitor well R: prepared for the City of Cocoa, secs. 1-3, and apps. A-C.

De Wiest, R.J.M., 1967, Geohydrology: New York, John Wiley and Sons, Inc., 463 p.

Ferris, J.G., Knowles, D.B., Brown, R.H., and Stallman, R.W., 1962, Theory of aquifer tests: U.S. Geological Survey Water-Supply Paper 1536-E, 174 p.

Freeze, R.A., and Cherry, J.A., 1979, Groundwater: New Jersey, Prentice-Hall, Inc., 604 p.

Galloway, Devin, and Rojstaczer, Stuart, 1988, Analysis of the frequency response of water levels in wells to earth tides and atmospheric loading: Proceedings, Fourth Canadian/American Conference on Hydrogeology, National Water Well Association, Dublin, Ohio, p. 100-113.
Hantush, M.S., 1964, Hydraulics of wells, in Chow, Ven Te, ed., Advances in hydroscience, v. 1: New York, Academic Press Inc., p. 281-442.

Healy, H.G., 1962, Piezometric surface of the Floridan aquifer in Florida July 6-17, 1961: Florida Geological Survey Map Series No. 1.

1975, Potentiometric surface and areas of artesian flow of the Floridan aquifer in Florida, May 1974: Florida Geological Survey Map Series No. 73.

Hickey, J.J., 1989, An approach to the field study of hydraulic gradients in variable-salinity ground water: Ground Water, v. 27, no. 4, p. 531-539.

1990, An assessment of the flow of variable-salinity ground water in the middle confining unit of the Floridan aquifer system, west-central Florida: U.S. Geological Survey Water-Resources Investigations Report 89-4142, 13 p.

Javandel, I., and Witherspoon, P.A., 1980, A semianalytical solution for partial penetration in two-layer aquifers: Water Resources Research, v. 16, no. 6, p. 1099-1106.

Lichtler, W.F., Anderson, Warren, and Joyner, B.F., 1968, Water Resources of Orange County, Florida: Florida Geological Survey Report of Investigations 50, 150 p.

Lohman, S.W., 1972, Ground-Water Hydraulics: U.S. Geological Survey Professional Paper 708, 70 p.

Lusczynski, N.J., 1961, Head and flow of ground water of variable density: Water Resources Research, v. 66, no. 12 , p. $4247-4256$.

Miller, J.A., 1986, Hydrogeologic framework of the Floridan aquifer system in Florida and in parts of Georgia, Alabama, and South Carolina: U.S. Geological Survey Professional Paper 1403-B, 91 p.

National Oceanic and Atmospheric Administration, 1992, Climatography of the United States, no. 81, Monthly station normals of temperature, precipitation, and heating and cooling degree days, 1961-90: Asheville, N.C., National Climatic Data Center, 28 p.

1994, Climatological data, annual summary for Florida, 1994: Asheville, N.C., National Climatic Data Center, v. 98, no. 13.

Neuman, S. P. and Witherspoon, P.A., 1972, Field determination of the hydraulic properties of leaky multiple aquifer systems: Water Resources Research, v. 8, no. 5, p. 1284-1298.

Oberlander, P.L., 1989, Fluid density and gravitational variations in deep boreholes and their effect on fluid potential: Ground Water, v. 27, no. 3, p. 341-350.

Reilly, T.E., 1993, Analysis of ground-water systems in freshwater-saltwater environments in Alley, William M., editor, Regional ground-water quality: Van Nostrand Reinhold, New York, pop. 443-469. 
Ritzi, R.W., Jr., Sorooshian, Soroosh, and Hsieh, P.A., 1991, The estimation of fluid flow properties from the response of water levels in wells to the combined atmospheric and earth tide forces: Water Resources Research, v. 27, no. 5, p. 883-893.

Sepulveda, Nicasio, 1992, Computer algorithm for the analysis of underdamped and overdamped water-level responses in slug tests: U.S. Geological Survey WaterResources Investigations Report 91-4162, 20 p.

Spechler, R.M., 1994, Saltwater intrusion and quality of water in the Floridan aquifer system, northeastern Florida: U.S. Geological Survey Water-Resources Investigations Report 92-4174, 76 p.

Thayer, P.A. and Miller, J.A., 1984, Petrology of lower and middle Eocene carbonate rocks, Floridan aquifer, central Florida: Transactions, Gulf Coast Association of Geological Societies, v. 34, p. 421-434.
Tibbals, C.H., 1990, Hydrology of the Floridan aquifer system in east-central Florida: U.S. Geological Survey Professional Paper 1403-E, 98 p.

Tibbals, C.H., and Frazee, J.M., Jr., 1976, Ground-water hydrology of the Cocoa well-field area, Orange County, Florida: U.S. Geological Survey Open-File Report 75-676, 67 p.

Tibbals, C.H., and Grubb, H.F., 1982, Aquifer test results, Green Swamp area, Florida: U.S. Geological Survey Water-Resources Investigations 82-35, 29 p.

U.S. Geological Survey, 1994, Water resources data, Florida, water year 1994: Water Data Report FL-94-1B, 281 p.

Van der Kamp, Garth, 1976, Determining aquifer transmissivity by means of well response tests: The underdamped case: Water Resources Research, v. 12, no. 1, p. 71-77. 